ENCUESTA 



\section{ENCUESTA SOBRE LA LIBERTAD DE EXPRESIÓN}

\section{PRESENTACIÓN}

Teoría y Realidad Constitucional ha prestado particular atención en encuestas anteriores a diversos temas relacionados con el correcto funcionamiento del Estado democrático, como los partidos políticos, la independencia de los medios de comunicación social o la representación política. Esta preocupación por la salud de nuestro sistema democrático es la que nos ha llevado a diseñar la encuesta sobre la libertad de expresión que abre este número de la revista.

Que la libertad de expresión es pieza esencial y determinante en el funcionamiento de los Estados democráticos no necesita mayor explicación. Ya lo reconoció nuestro Tribunal Constitucional en una de sus primeras decisiones, la STC 6/1981, expresando tal idea en unos términos rotundos e inequívocos que todos recordamos: la libertad de expresión «garantiza el mantenimiento de una comunicación pública libre, sin la cual quedarían vaciados de contenido real otros derechos que la Constitución consagra, reducidas a formas hueras las instituciones representativas y absolutamente falseado el principio de legitimidad democrática que enuncia el art. 1.2 de la Constitución, y que es la base de toda nuestra ordenación jurídico-política». Por este motivo, en todos los sistemas democráticos se reconoce y protege la libertad de expresión, no sólo para satisfacer, como derecho fundamental subjetivo, la necesidad esencial básica de las personas de exteriorizar sus ideas, pensamientos y opiniones, como parte del proceso de desarrollo libre de su personalidad, sino también, y especialmente, para asegurar el correcto funcionamiento democrático del Estado.

Podría parecer que, al tratarse de una libertad clásica, y estando todos de acuerdo en la necesidad de su reconocimiento y protección, hoy la libertad de expresión no presenta una especial problemática a la que los estudiosos del derecho constitucional tengan que hacer frente. Sin embargo, la realidad de estas primeras décadas del siglo XXI nos hace pensar que no es así, sino que vamos a vernos obligados a reflexionar sobre el papel que juega hoy esta libertad fundamental, sobre las actividades que deben formar parte de su ámbito protegido, sobre los límites que puede o debe encontrarse y, en definitiva, sobre el mejor modo de mantener vivos nuestros Estados democráticos.

Para empezar, los procesos de la comunicación en los que tiene lugar la formación de la opinión pública libre se han transformado profundamente. Ya no se 
trata de que haya nuevos medios de comunicación, sino de que la forma en la que los ciudadanos se forman, se informan y se entretienen responde a un paradigma completamente distinto al que rigió hasta hace una década, y en ello tienen mucho que ver las nuevas tecnologías y los cambios sociales que éstas han traído consigo. ¿Podrá la libertad de expresión seguir cumpliendo su papel en este nuevo entorno? De otro lado, la sociedad parece haber cambiado su consideración sobre el tipo de mensajes que deben quedar protegidos por la libertad de expresión, haciendo una interpretación mucho más estricta que la que hacía antes, de modo que hoy discutimos sobre si los llamados discursos del odio, los mensajes políticamente incorrectos, las expresiones artísticas de dudoso gusto, o el humor satírico e irrespetuoso deben estar amparados por esta libertad o no. Finalmente, a propósito de estas preguntas nos parece relevante reflexionar sobre las categorías de la teoría general de los derechos fundamentales y sobre las herramientas jurídicas que utilizan los tribunales para determinar en cada caso concreto de conflicto si estamos ante un ejercicio legítimo de la libertad de expresión.

Las cuestiones citadas y otras semejantes nos llevaron al convencimiento de que Teoría y Realidad Constitucional debía convocar a un buen grupo de expertos constitucionalistas, especializados en el derecho fundamental a la libertad de expresión, para que nos orientasen con su sabiduría y enriqueciesen el necesario debate sobre esta libertad. El lector encontrará en las respuestas a la encuesta rigor teórico, conocimiento de la realidad, algunos pensamientos críticos e ideas sugerentes que invitan a la reflexión y al estudio de esta materia.

\section{CUESTIONES}

1. La libertad de expresión ha servido siempre a la garantía de los procesos de formación libre de la opinión en los que se apoya el Estado democrático. ¿Cree que puede hacerlo de la misma manera ante las nuevas formas de comunicación e información que hoy existen, como las redes sociales e internet?

2. ¿Qué reflexiones nos quiere hacer sobre el llamado "discurso del odio» y sobre los límites de la libertad de expresión? ¿Considera que la libertad de expresión no debe proteger determinado tipo de discursos?

3. ¿Cómo valora el becho de que ciertas expresiones (artísticas, musicales, bumoristicas...) que hace un par de décadas se consideraban ejercicio de la libertad de expresión hoy, sin embargo, no se entiendan protegidas por esta libertad? ¿A qué cree que se pueden deber estos cambios?

4. Recientemente el TEDH ha considerado que una condena penal impuesta por España era contraria a la libertad de expresión ¿Cree que sería conveniente algún tipo de reforma respecto a los limites penales de esta libertad?

5. La jurisprudencia del Tribunal Constitucional sobre las libertades de expresión e información se ha centrado, sobre todo, en el conflicto entre estas y los derechos de la personalidad ¿Qué valoración general le merece dicha jurisprudencia? 
6. Como ba ocurrido con otros derechos fundamentales, el ámbito de protección de la libertad de expresión se ha ido ampliando para entender incluidas actividades nuevas, como, por ejemplo, la publicidad ¿Qué opinión le merece esta tendencia en general, y en concreto en el caso de la libertad de expresión?

7. ¿Cómo valora el uso del principio de proporcionalidad para determinar si, en caso concreto, una determinada actividad está protegida por la libertad de expresión? ¿Cree que una mejor delimitación del ámbito protegido y/o una recuperación del concepto de contenido esencial podrian ayudar a resolver con mayor seguridad los conflictos relativos al ejercicio de esta libertad?

\section{ENCUESTADOS}

MARC CARRILLO LÓPEZ, Catedrático de Derecho Constitucional, Universidad Pompeu Fabra

LORETO CORREDOIRA ALFONSO, Profesora Titular de Derecho Constitucional, Universidad Complutense de Madrid

ÁNGEL RODRÍGUEZ, Catedrático de Derecho Constitucional, Universidad de Málaga

REMEDIO SÁNCHEZ FÉRRIZ, Catedrática de Derecho Constitucional, Universidad de Valencia

JUAN JOSÉ SOLOZÁBAL ECHAVARRÍA, Catedrático de Derecho Constitucional, Universidad Autónoma de Madrid

JOAQUIN URÍAS MARTÍNEZ, Profesor Titular de Derecho Constitucional, Universidad de Sevilla

IGNACIO VILLAVERDE MENÉNDEZ, Catedrático de Derecho Constitucional, Universidad de Oviedo

\section{RESPUESTAS}

1. La libertad de expresión ha servido siempre a la garantía de los procesos de formación libre de la opinión en los que se apoya el Estado democrático. ¿Cree que puede hacerlo de la misma manera ante las nuevas formas de comunicación e información que hoy existen, como las redes sociales e internet?

\section{MARC CARRILLO LÓPEZ}

El impacto de Internet y los cuatro gigantes del sector (Google, Facebook, Amazon y Microsoft) y la diversidad de las redes sociales sobre el entorno individual y colectivo de las personas, constituye uno de los grandes retos al que se enfrenta el Derecho. A diferencia de lo que en alguna ocasión había sostenido 
algún órgano judicial en España, Internet es también un instrumento para la comunicación. Fue el caso protagonizado por la sentencia del Juzgado de lo Penal n. ${ }^{\circ} 16$ de Madrid de 18 de diciembre de 2009, que condenó a dos periodistas de la Cadena Ser por revelación de secretos a una pena de un año y nueve meses de prisión, en la que se sostenía que «Internet no es un medio de comunicación social en sentido estricto, sino universal». El sistema procesal de recursos permitió que este despropósito interpretativo no prosperase. No hay duda de que Internet es también - iy de qué manera! - un medio para expresarse e informar.

A treinta años de la creación de la World Wide Web el 12 de marzo de 1989, la llamada Red no es un paraíso. Concebida en sus inicios como una plataforma ideal para acrecentar la libertad en una sociedad global y devenir a la vez un excelente instrumento para la participación social de ciudadanos y corporaciones, la realidad que muestra su desarrollo, además de sus indudables luces, no puede obviar tampoco el impacto potencialmente lesivo que presentan sus sombras sobre la garantía efectiva de los derechos y libertades en el Estado democrático. La perversión del sentido de la libertad de expresión e información y la vulnerabilidad a la que, en ocasiones, se ve abocada la garantía efectiva de los derechos por un uso espurio de las redes sociales en la sociedad digital, exige del Derecho dar respuesta al reto de la regulación del ciberespacio. Una regulación que desde luego no puede ser estatal sino forzosamente transfronteriza. Lo contrario sería ilusorio. A fin de preservar con ello los objetivos de la libertad de expresión e información como derechos que garantizan el mantenimiento de una comunicación pública libre, sin la cual quedarían vaciados de contenido real otros derechos reconocidos por la Constitución, como los derechos de la personalidad, y reducidas a formas hueras las instituciones representativas, tal como estableció el Tribunal Constitucional en la interpretación que hizo fortuna contenida en su célebre STC 6/1981.

En la reflexión sobre la libertad de expresión contenida en un libro reciente publicado en traducción castellana en 2017, de Timothy Garton Ash, se expone lo que para este historiador y politólogo inglés son los diez principios para un mundo conectado. El noveno lo formula así: «Defendemos internet y otros sistemas de comunicación contra las intrusiones ilegítimas de los poderes tanto públicos como privados». Y, en efecto, todas las bondades que presenta la Red pueden quedar enervadas tanto por la acción de los Estados como, incluso, y en mayor grado, por las empresas y corporaciones privadas dadas las enormes posibilidades que Internet ofrece para influir y condicionar las conciencias.

Los avances que la evolución tecnológica ha producido sobre las diversas plataformas de expresión del pensamiento a lo largo de la historia siempre han suscitado juicios políticos y morales, que en ocasiones se han mostrados exorbitantes fruto, sin duda, de un cierto determinismo tecnológico. Así lo fue con la imprenta, el telégrafo o el fax. Y también lo ha sido con Internet, cuya aparición se asimiló por algunos a un paraíso abierto para la libertad, y para otros como un campo abonado para el feudalismo empresarial y el control autoritario de los Estados. 
Específicamente, para la libertad de expresión el carácter potencialmente universal de Internet permite, sin duda, ofrecer un ámbito liberador para la ciudadanía como sujeto activo y titular de ese derecho fundamental. Pero al mismo tiempo y sin solución de continuidad, como subraya Garton Ash, alberga un poder opresivo, incluyendo la amenaza a la libertad de expresión. Porque, en este sentido, no puede pasar desapercibido que cuando las grandes empresas de Internet invierten cantidades superiores a las empresas petrolíferas para ofrecer sus productos a través de la Red no lo hacen de forma neutral. Recientemente, Evgeny Mozorov subrayaba al respecto que «[N]uestra libertad en Internet no era más que un subproducto de un negocio y unos modelos de vigilancia poco desarrollados» (El País, 5/5/2019, Ideas, p. 2).

Desde el ámbito del Derecho la respuesta al reto que plantea la libertad de expresión en la Red ha de partir de la premisa de que Internet nunca puede ser concebido como un ámbito a extramuros del ordenamiento jurídico. No es una especie de área autónoma abierta al espíritu libertario del usuario. Así, por ejemplo, preservar la libertad de expresión como garantía de los procesos de formación libre de la opinión en los que se apoya el Estado democrático exige que la aplicación de las reglas interpretativas asentadas por la jurisprudencia constitucional y convencional para resolver la colisión entre la libertad de expresión y los derechos de la personalidad no pueden considerarse ajenas al mundo de la Red.

Ciertamente, pueden resultar y de hecho resultan insuficientes. La red ofrece nuevos aspectos de indudable relevancia jurídica que exigen de los operadores jurídicos la aportación de nuevos criterios hermenéuticos acordes con la singularidad de Internet como instrumento de comunicación. Ahora bien, lo que resulta evidente es que el Derecho no puede mirar para otro lado ante una realidad especialmente invasiva y en la que las libertades pueden resultar malparadas. Por ejemplo, uno de los problemas con los que se enfrentan las libertades de expresión e información en Internet es la determinación de la autoría y la fijación de responsabilidades, como se puso de manifiesto en la STJUE de 13 de mayo de 2014, Caso Google Spain/AEPD y M. Costeja). Otro es el relativo a la determinación de los derechos de autor. Problema arduo que recientemente el Parlamento europeo trata de abordar a través de la fijación de unas bases jurídicas para su regulación en el ámbito digital, mediante la reciente resolución legislativa de 26 de marzo de 2019.

\section{LORETO CORREDOIRA ALFONSO}

En cada época este derecho fundamental, analizado ya desde el siglo Xx como derecho, que no sólo libertad, ha cumplido su función y especialmente en su relación con los Estados o, antes del Estado moderno, con los Reyes soberanos.

En el siglo XVIII se reconoce ya en los primeros textos internacionales si bien, ya desde la Carta de Juan Sin Tierra en la Inglaterra del siglo XII o en las «Lectiones» 
de Francisco de Vitoria en la Escuela de Salamanca se vislumbra el carácter imprescindible de este «ius communicationis» en las democracias.

Desde estos textos, incluyendo nuestra Constitución de Cádiz de 1812, hasta el Decreto de Libertad de Expresión del presidente Adolfo Suárez en 1977 en lo contemporáneo, se ve siempre esa tensión de la libertad de imprimir, acartelar, emitir por radio o comunicar libremente, y el poder o el afán de control. Hoy con las Redes Sociales e Internet, los conflictos son muy parecidos, aunque se están pudiendo amplificar por su impacto general en la ciudadanía. De los escasos lectores de prensa hemos pasado a los millones de usuarios de Facebook, YouTube o Twitter, pero los principios entiendo que son los mismos.

Su naturaleza de derecho básico de las sociedades organizadas se pone de manifiesto ya desde sus precedentes como han puesto de manifiesto Remedio Sánchez Ferriz o José M. ${ }^{a}$ Desantes en las primeras obras del Derecho de la Información en España en los años 70.

El artículo 19 de la Declaración Universal de Derechos Humanos de la ONU proclama la «universalidad del derecho» en modo (forma de expresión), medio (impreso, radio, tv o Internet) y en lo geográfico. Por lo tanto, es una garantía necesaria, como la existencia misma del pluralismo político y las elecciones libres, e incluso diría que es además, condición para que haya pluralidad de ideas, partidos, opiniones, y de línea editorial en los medios informativos o portales de noticias.

\section{ÁNGEL RODRÍGUEZ}

Hace ya algún tiempo, el profesor Peter Häberle advirtió que nos hacía falta una teoría constitucional de los medios de comunicación de masas. La realidad, me temo, ha superado ya el diagnóstico del gran constitucionalista alemán: de lo que andamos ahora verdaderamente necesitados es de una teoría constitucional de internet.

Me parece evidente que la presencia de esas nuevas formas de comunicación obliga a adaptar nuestra visión del papel de la libertad de expresión a una realidad social que poco se parece a la de hace unos años. Creo que sigue siendo igual de válida la doctrina clásica sobre la libertad de expresión como fundamento de una opinión pública libre, sin la cual «quedarían vaciados de contenido real otros derechos que la Constitución consagra, reducidas a formas hueras las instituciones representativas y absolutamente falseado el principio de legitimidad democrática», como de manera muy afortunada proclamara nuestro mejor Tribunal Constitucional en una de sus primeras sentencias, hace ya casi cuatro décadas (STC 6/1981, F.J. 3. ${ }^{\circ}$ ). Sin embargo, es posible que la eclosión de internet nos obligue a plantearnos algunos de los corolarios que generalmente han venido asociados a esa proclamación, particularmente los relacionados con la a veces no muy bien comprendida "posición preferente» de este derecho fundamental (sobre la que algo se dice en la pregunta séptima). 
La línea en la que convendría avanzar supone, creo, profundizar en los «deberes y responsabilidades» que entraña el ejercicio de nuestra libertad cuando nos expresamos a través de internet y las «formalidades, condiciones, restricciones o sanciones» que, también en palabras del art. $10 \mathrm{CEDH}$, podría implicar su ejercicio. Por supuesto que, como todo lo que afecta — limitándola - a la libertad de expresión, hacerlo está plagado de riesgos y dificultades (algunos se mencionan en las respuestas subsiguientes de esta encuesta), por lo que es una tarea que habría que abordar con muchas cautelas. Pero la existencia de esos problemas no debería ser una excusa para no emprenderla.

En mi opinión, el mundo en red que se está construyendo ha introducido dos grandes cambios en el papel que la libertad de expresión tiene en nuestras sociedades (y ello por no mencionar otros que también afectan a la cuestión que ahora tratamos, aunque de manera menos directa: la desaparición de la intimidad, la tiranía de los algoritmos o el derecho al olvido, por ejemplo). El primer gran cambio es el progresivo desvanecimiento de la frontera entre el discurso público y el privado; el segundo, que los medios de comunicación «institucionalizados» (la expresión la ha usado en reiteradas ocasiones nuestro TC) han dejado de ser los agentes intermediadores más relevantes en la conformación de la opinión pública, particularmente en lo que los expertos en comunicación denominan el proceso de «agenda setting». Ambos fenómenos tienen, o deberían tener, consecuencias jurídicas.

En cuanto al primero de ellos, tradicionalmente el ordenamiento ha concedido relevancia jurídica a la hora de proteger o restringir un mensaje al hecho de que este se formulara en privado o en público. La publicidad sigue siendo, por ejemplo, un agravante en los delitos de injurias o calumnias, mientras que las expresiones vertidas en la intimidad o con carácter privado tienden a carecer de límites que puedan imponerse desde el derecho, pues se trata de un terreno, el del discurso privado, cuyo régimen jurídico, al que puede sumarse la garantía del secreto de las comunicaciones, se aproxima al de la libertad de pensamiento. Este esquema salta con los aires con el uso indiscriminado de las redes sociales, donde a menudo se vierten mensajes llamados a tener una gran difusión, aunque no siempre sea esa la intencionalidad del autor, y que con frecuencia han sido elaborados con el formato y los códigos propios de las expresiones privadas. En los mensajes que pueblan las redes es difícil distinguir entre lo que se dijo con la intención de que fuera conocido solo por un grupo reducido de interlocutores y lo que no. Internet se parece cada vez más a una taberna que a un ágora. (Puede que no sea una anécdota que el grupo más dinámico de mis estudiantes del grado en periodismo de hace unos cursos decidiera crear un periódico digital universitario precisamente con ese nombre: «La taberna global»).

El segundo fenómeno también ha sido descrito por los observadores del mundo digital: sigue habiendo medios de comunicación que trasladan al público noticias contrastadas y opiniones solventes, pero en la mayoría de los casos la opinión pública se forma ya sin su intermediación. Junto a esos medios profesionalizados, 
pueblan las redes empresas especializadas en relaciones públicas, cuando no en la propaganda y la intoxicación, que son auténticas fábricas de noticias falsas («fake news»). Además, y en pie de igualdad con las anteriores, actúan un ilimitado número de personas que, lejos de cumplir los augurios más optimistas de una época dorada de democratización de la información protagonizada por los nuevos «citizen journalists», combaten el malestar que a todos nos crea la «disonancia cognitiva» de la que nos habla la psicología social, ocasionado por la discrepancia entre la realidad y los prejuicios, esparciendo y retroalimentando los fragmentos de realidad que menos entran en conflicto con los suyos propios. Desde la aparición de las redes sociales, la intermediación de la prensa en el flujo de información no ha hecho más que disminuir, para bien y para mal. Se trata, en mi opinión, de un fenómeno íntimamente ligado, y con efectos comparables, con lo ocurrido con el papel de los partidos políticos en las modernas democracias. También a este último respecto, su debilitamiento como estructuras de intermediación ha propiciado, sobre todo, una seria crisis de la democracia representativa. Está por ver si, como piensan algunos, esa crisis irá seguida de un florecimiento de la democracia participativa o, por el contrario, de «democraduras» de corte plebiscitario

\section{REMEDIO SÁNCHEZ FÉRRIZ}

La libertad de expresión es en nuestro ordenamiento un derecho fundamental, aunque yo prefiero hablar de una libertad pública y, más en concreto, de su condición de matriz de las libertades públicas. Ello justificaría por sí solo su papel axial en toda democracia real. Pero no sólo en el presente. Si recordamos el origen y configuración del Estado Liberal, esta libertad está en la base de las ideas y realidades que confluyen en las nuevas formaciones estatales; en lo que a nosotros se refiere, baste recordar el ambiente social y el texto discutido en el Cádiz de 1812.

Pero la extraordinaria significación de la libertad de expresión en un régimen constitucional democrático no puede comportar omnipresencia u omnifunción que desconozca otros aspectos y bienes jurídicos de nuestro ordenamiento. El Tribunal Constitucional repite a menudo que ningún derecho es absoluto; pero yo creo que decir esto es como no decir nada por su excesiva relatividad que nada resuelve. Creo que los derechos son más absolutos cuanto más se ciñen a su propio ámbito de actuación. Es cierto que la libertad de expresión dispone de amplísimos ámbitos en los que desplegar todo su potencial, pero no por ello ha de considerarse ajena al respeto del ordenamiento jurídico en el que concurre el respeto a los valores y la protección de múltiples bienes jurídicos tan fundamentales, y a veces más, que la propia libertad de expresión.

La sociedad democrática, su ámbito y sus necesidades, en la forma que tan a menudo se invoca en el conocido test del TEDH, no tiene por qué ser una 
sociedad soez; no debería. Y, sin embargo, en las últimas décadas y, en especial, cuando la libertad de expresión es un instrumento o auxiliar de la libertad artística o creativa, o de la ideológica se ve especialmente potenciada. Además, los avances tecnológicos potencian extraordinariamente sus efectos, tanto los positivos como los negativos o de afectación de otros bienes jurídicos. Es más, la ampliación de nuevos espacios y medios ha introducido con naturalidad manifestaciones soeces, irreverentes y ofensivas que, por más que como dijera Cicerón, no todo lo molesto es delito (y es cierto), dudo que deban ser alentados por cuanto acaban conformando referentes sociales e idearios supuestamente más democráticos para las jóvenes generaciones que sí pueden creer que la calidad democrática aumenta con el indiscriminado uso del lenguaje. Aunque una cosa es el uso de una lengua rica y prolífica en matices como es la nuestra (cuya corrección no exime de imputación si hay daño a terceros) y otra bien distinta querer hallar amparo constitucional para cualquier manifestación oral o escrita e incluso simbólica, cosa que las redes sociales potencian extraordinariamente en forma sin duda imposible de imaginar por los constituyentes.

La cuestión, a mi juicio, debe pasar por la mayor delimitación posible del ámbito de protección a partir de la precisión del concepto y de su aplicación en la realidad. Es cierto que resulta más fácil determinar el derecho a la información para el que la Constitución exige notoriedad y veracidad; pero tampoco el amplísimo ámbito de la libertad de expresión puede desconocer el significado lógico del objeto (u objetos) que la propia Constitución le ofrece: se trata de la manifestación, por cualquier medio, de las ideas, pensamientos y opiniones. Lo que no es poco; pero, siendo tantas las posibilidades de ideas, pensamientos y opiniones, no parece que puedan contener en sí mismas elementos susceptibles de distorsionar la normal convivencia o lo que el art. 10 denomina paz social, sin perjuicio de puntuales episodios de escasa fortuna (pero involuntarios) que pueden presentarse a cualquiera, y más con la participación que hoy nos posibilitan las redes sociales. No en vano, el art. 578 del Código Penal vigente menciona en diversas ocasiones «la difusión de servicios o contenidos accesibles al público a través de medios de comunicación, internet, o por medio de servicios de comunicaciones electrónicas o mediante el uso de tecnologías de la información», tanto para ser valorado el tipo como a la hora de establecer las consecuencias de una condena a través de tales medios.

La potencia que las redes sociales aportan al uso de la libertad de expresión es tal que cabría pensar en la necesidad de una regulación distinta a la de los medios tradicionales. Sin embargo, coincido con Boix (REP, 2016) en que el mensaje en si mismo no tiene por qué merecer una valoración distinta en función de su uso en red social o en medios tradicionales. Cuestión distinta es que las redes sociales puedan comportar en casos concretos riesgos por su repetitividad, rapidez e irreflexión; pero será cada caso concreto el que habrá de juzgarse sin que el medio por sí mismo pueda imponer una regulación diferenciada. Si acaso, yo añadiría una consideración que no debe ignorar el Juzgador; es la referida a sus 
destinatarios, sin duda mucho más jóvenes que quienes leen la prensa, incluso digital.

\section{JUAN JOSÉ SOLOZÁBAL ECHAVARRÍA}

(Respuesta conjunta a todas las preguntas de la encuesta)

I. Aunque centraré mis comentarios en torno a la Sentencia del Tribunal de Derechos Humanos de Estrasburgo que plantea el entendimiento correcto, en el supuesto a que se refiere, de la inviolabilidad del monarca y del discurso del odio, es necesario aludir a tres cuestiones relacionadas con el objeto de mi comentario. En primer lugar, he de suscitar el problema de la precomprensión de la libertad de expresión o si se quiere el contexto, intelectual, desde la que, a mi juicio, deben abordarse los problemas concretos de la libertad de expresión. En segundo lugar, me referiré a los términos generales en que han de situarse los conflictos de la libertad de expresión en relación con las exigencias de su compatibilidad con otros bienes y derechos. En tercer lugar, trataré de señalar algo sobre la especificidad de la problemática de la libertad de expresión en relación con los medios a través de los cuales se lleva a cabo hoy mayormente el ejercicio de esta libertad de comunicación.

a) Nuestra precomprensión de la libertad de expresión, en razón con la contribución de este derecho a la vida democrática y su imprescindibilidad en el aseguramiento de la dignidad de la persona, nos lleva a una visión irrestricta de la misma. Si se trata de entender la sustancia de los derechos fundamentales, esto es, la relación de los mismos, de una parte, con la dignidad de la persona y, de otra, con el funcionamiento del sistema democrático, dando cuenta tanto de su indefectibilidad como de su importancia, el ejemplo a poner es la libertad de expresión. Callar a alguien cuando quiere hablar, o censurarle o amenazarle con represalias por lo que diga, es tratarle de modo vejatorio, impidiendo su desenvolvimiento como persona, pues somos seres locuaces, a los que el silencio no querido reduce al aislamiento y la incomunicación. De otro lado, los sistemas democráticos no funcionan sin libertad para criticar al poder, y la participación política en los mismos exige ciudadanos informados, que han podido formarse una idea correcta acerca de lo que las diversas opciones de gobierno que se disputan las elecciones ofrecen.

Quizás el argumento que prima en la justificación de la libertad de expresión es el argumento político, de modo que solo con la libertad de expresión irrestricta se asegura que al final se oiga lo que la comunidad necesita. Como ha escrito Post de lo que va la libertad de expresión es de un speech político sobre el gobierno, se le critique o se le defienda. Un gobierno criticado es un gobierno justificado funcionalmente, pues el mismo aumenta su legitimación si sus decisiones pueden alegar el respaldo de la sociedad que las ha discutido; además la eficiencia de tal gobierno aumenta si la comunidad ha tenido la oportunidad de conocer sus 
problemas y proponer su tratamiento adecuado en un debate público. Timothy Garton Ash por su parte ha mostrado los inconvenientes o las repercusiones negativas de la represión sobre la libertad de expresión, llamando la atención sobre el mal ejemplo que Occidente da cuando muestra una predisposición para limitar la libertad, mediante la tipificación penal contra el terrorismo, el lenguaje del odio, la legislación sobre la blasfemia o la defensa del honor de los jefes de Estado extranjeros. La tesis de este autor es que la defensa templada de la libertad de expresión en Occidente alienta los abusos de los regímenes autoritarios en otras partes del mundo.

Esta idea irrestricta de la libertad de expresión que yo asumo como planteamiento de fondo, la considera un derecho fundamental, reconocido en la Constitución, cuya prohibición e incluso limitación ha de ser la excepción, de acuerdo con las previsiones de la ley. En realidad, solo se admiten tres límites a la libertad de expresión, a saber, la pornografía infantil, la publicación de datos nucleares que pongan en peligro la seguridad del Estado, y la incitación a la violencia, pero solo, cuando atendidas las circunstancias del caso, constituyese una amenaza seria e inminente.

Es importante señalar que los costes del ejercicio de esta visión irrestricta pueden ser altos: los exija el poder público tirano, mediante la censura y la represión, a través de la actuación de una autoridad no sometida a ley o se trate de una circunstancia cuando los ciudadanos no disponen de un estándar prohibido de conducta, correctamente tipificado, con el debido rango normativo y asegurándose las garantías jurisdiccionales suficientes. $\mathrm{O}$ se ignore que la libertad de expresión requiere de una sociedad civil tolerante que acepte la incomodidad grave que supone la libertad de expresión, y esté dispuesta a que se remuevan los convencionalismos y se pongan en cuestión sus más firmes bases ideológicas o morales.

b) Sabido es que los problemas más interesantes que presentan los derechos fundamentales se refieren a su limitación, exigida, de un lado, del aseguramiento de su ejercicio en un ordenamiento que debe garantizar, simultáneamente, el disfrute de ese derecho por parte de los demás; y consecuencia, de otra parte, del requerimiento de respeto de otros derechos y bienes jurídico constitucionales. Durante mucho tiempo se entendió que, atendidos los mismos términos de su reconocimiento constitucional, en el que puede ya descubrirse una configuración del derecho, los problemas de la limitación se salvaban con la observancia del contenido esencial, como límite de límites. Lo que ocurre es que los problemas de esta categoría son múltiples, nos refiramos a su condición meramente declaratoria, la indeterminación de su alcance o la condición de sus destinatarios en la cláusula constitucional que impone su observancia.

En cualquier caso, la virtualidad del principio desaparece cuando el conflicto entre derechos se produce en términos en que no es posible la composición, a través de una actuación de ponderación que lleva a la «concordancia práctica», sino que sólo es resoluble en términos de prevalencia. En tales ejemplos, como 
decimos, el del contenido esencial no es un límite absoluto que proteja en caso de conflicto a los derechos en pugna, porque hay conflictos sencillamente no resolubles por medio de la acomodación sino, en ese supuesto concreto y no de modo permanente o incondicionado, a través de la imposición del derecho prevalente. Lo que sí parece, en todo caso, es que el límite del contenido esencial opera como un mandato de optimización de los derechos, al afirmarse, en principio el acomodo de los mismos.

Las dificultades que presenta la utilización del principio del contenido esencial como criterio a través del que resolver las cuestiones sobre la constitucionalidad de la limitación de los derechos han acabado determinando su sustitución por la aplicación del principio de proporcionalidad a dicho efecto. Su sentido general se capta caracterizándolo como un principio técnico de control de la arbitrariedad del legislador. Proporcionalidad quiere decir para el legislador que las regulaciones y habilitaciones legales con un significado invasor de los derechos fundamentales deben ser apropiadas y necesarias para alcanzar su finalidad respectiva, que a su vez debe ser constitucionalmente legítima.

Pero el recurso a este principio en relación con el legislador tampoco está exento de problemas, comenzando por la ausencia de su reconocimiento constitucional. Ciertamente su justificación es más clara en el ámbito administrativo en el que el principio sirve de referencia para el control de la administración con una cobertura legal escasa, en el supuesto de materias en las que la ley hace poco más que abrir el paso a la actuación administrativa, normativa o concreta, pero sin cubrirla necesariamente. El caso es que esta dificultad no ha arredado al Tribunal Constitucional a recurrir a este expediente, especialmente en materia penal. El Tribunal Constitucional acoge un criterio técnico de proporcionalidad que exige que exista relación entre la gravedad de la infracción y la entidad de la pena. Se entiende que el legislador se ha atenido al principio, siempre que la pena se justifique aplicando el test de la proporcionalidad, esto es, que exista necesidad de tipificación penal, dado el ataque que sufre el bien jurídico correspondiente; que la medida sea adecuada; y, por último, que suponga una intervención mínima que no ponga en peligro la adecuación o idoneidad, así como la necesidad o justificación de la medida.

A nuestro juicio la experiencia de la utilización de este criterio de actuación del Tribunal Constitucional lo que muestra es el peligro del empleo como parámetro de constitucionalidad no ya de prescripciones constitucionales concretas, sino de pautas de simple razonabilidad, que, a pesar de su aparente presentación técnica, amenazan con inhibir facultades de creación normativa que a quien corresponden verdaderamente es al legislador.

Lo que indicaría el uso de estos dos criterios de limitación del legislador es la dificultad de entender correctamente las relaciones entre Constitución y derecho penal. Cierto que no cabe un ejercicio de los derechos fundamentales ilegal; pero tampoco cabe la penalización de conductas que no pueden estar prohibidas porque se refieren al disfrute de bienes jurídicos reconocidos constitucionalmente. 
c) Una puntualización final en estas observaciones preliminares. No puede negarse la trascendencia que la llegada de la comunicación a través de internet ha producido en la problemática que nos ocupa. Internet ha incrementado las oportunidades de participación para los ciudadanos, baste pensar en la transparencia de la actuación del poder que favorece y su contribución a la movilización, que es instantánea y de cero costes. Sin duda con Internet el poder pierde lejanía y opacidad. La cuestión estriba en que el incremento de la densidad comunicativa que internet hace posible, y las oportunidades de la afectación de otros derechos que este medio significa, no deben alterar la protección debida a la libertad de expresión que debe continuar asegurada cualquiera sea el medio por el que se ejerza, claramente así cuando estamos hablando de internet. La garantía y el control del derecho siempre debe corresponder en exclusiva a los jueces y tribunales, de modo que se descuente cualquier actuación preventiva y represiva de la administración. Esta indicación sirve tanto cuando estamos ante un supuesto concreto y simple de uso individual del derecho como cuando la manifestación del pensamiento corresponde a un medio o depende de actividades complejas como las que llevan a cabo servidores o instalaciones de Internet.

II. Como señalaba al principio centraré mi atención en la consideración de un caso cuyo estudio ilumina un posible límite a la libertad de expresión, el del llamado discurso del odio, en un supuesto en el que también se plantea el alcance de otra limitación como puede ser el respeto, en el ordenamiento español, de la inviolabilidad del monarca. Este caso puede servir también para poner de manifiesto las relaciones de la libertad de expresión con el ejercicio de otros derechos como el de manifestación o la libertad ideológica. Por lo demás la inviolabilidad del monarca no deja de ser el reverso de la actividad declarativa del monarca, cuando el Rey no es objeto sino un sujeto bien especial de la libertad de expresión. Como se sabe, en este último supuesto no estamos refiriéndonos a un caso de laboratorio o a una intervención protocolaria del monarca, pues la imparcialidad del monarca que se corresponde su función arbitral y moderadora, propia de su rol representativo general, no le impide actuar en la defensa del orden constitucional en aquellas circunstancias en que este corra serio peligro, como ocurrió en ocasión del golpe de Estado de febrero de1981 o de la revuelta institucional de Cataluña en los primeros días de octubre de 2017.

Por lo que hace a la actividad declarativa ordinaria del rey su admisión no ofrece problema alguno, pues la identificación del Rey con el sistema constitucional que se añade a la representación del Estado que lleva a cabo y a su condición de exponente de la sociedad española legitiman plenamente la intervención declarativa que éste cumple ocasionalmente a través de sus mensajes dirigidos a la nación. En otras Monarquías esta actividad del Rey no presenta problema alguno, pues a través de tales mensajes el Jefe del Estado no hace sino expresar la opinión, o el programa, del Gobierno en el poder. En España, creemos que afortunadamente, no se ha seguido esta pauta. El problema es establecer si estas declaraciones, que han de contar con el conocimiento previo a su emisión del 
Gobierno, pueden permitir el desarrollo de una línea discursiva, que aun siendo significativa, no implique al Rey en el juego político. Nosotros creemos efectivamente que existe suficiente espacio para una formulación autónoma, no partidista, consistente en la propuesta de una política constitucional, como desarrollo directo y evidente de los fines de este carácter en una determinada coyuntura, justamente el momento en que se pronuncia el discurso o se hace la declaración por el Rey. No es cierto, como se sabe, que la Constitución se limite a establecer un sistema abierto e igualitario de reglas de juego; supone también una opción por determinados fines, los del Estado material de derecho, aquellos objetivos que tienen que ver con un sistema político integrado, igualitario y respetuoso de la libertad y derechos de todos. La especificación de estos fines y el juicio sobre la actitud del sistema político respecto de los mismos supone un espacio en el que caben consideraciones no partidistas, pero claramente pertinentes por parte del Rey.

Pararemos entonces mientes en la doctrina que se desprende de algunos pronunciamientos del Tribunal de Derechos Humanos de Estrasburgo, y singularmente de la Sentencia sobre el caso Stern y Rouras del año pasado. La sentencia del TEDH, caso Stern Taulats y Roura Capellera contra España, de 13 de marzo del 2018 del Tribunal de Estrasburgo, como se recordará, otorgaba protección a estos dos ciudadanos españoles que habían sido condenados por los tribunales de instancia (Juzgado y Sala de la Audiencia Nacional y Tribunal Constitucional) por un delito de injurias contra el Rey por haber quemado un retrato de los Reyes de España. El Tribunal entendía que las sentencias citadas habían vulnerado la libertad de expresión de los manifestantes y que la conducta sancionada quedaba cubierta por la protección que a su crítica conferían los términos de protección de la libertad de expresión de los ordenamientos europeo y nacional.

Es importante decir que compartimos, y estimamos en mucho, la posición del Tribunal Europeo asumiendo una visión irrestricta y de claro potencial expansivo de la libertad de expresión. Creemos que el ciudadano tiene libertad no solo para apoyar a sus gobernantes sino para censurarlos y zaherirles con acritud, injusticia y malas maneras; y, así, suscribimos una reciente recomendación de The Economist : «No intentemos jamás silenciar a aquellos con los que discrepamos. Contestemos al discurso de nuestro oponente con más debate. Hemos de discutir sin recurrir a la violencia, y simplemente dispongámonos a endurecer nuestra piel».

Pero al lado de esto, nos parece importante llevar a efecto algunas precisiones. Así, como primera consideración, apuntaríamos, que el Tribunal Europeo al pronunciarse sobre el caso, ha dejado sin consideración la condición inviolable del monarca, que establece el artículo, 56 , apartado $3 .^{\circ} \mathrm{CE}$, que no figura en el material normativo a tener en cuenta por el Tribunal, que efectivamente no se refiere a esta cuestión. No estoy afirmando que la inviolabilidad del monarca (esto es, su inatacabilidad absoluta, expresión de su alta posición en el ordenamiento inviolables constitucionalmente solo son los derechos fundamentales y las 
Cortes-) se imponga a la crítica a la monarquía, ni tan siquiera en los supuestos más acerbos de la misma, cuando se lleva a cabo mediante la quema del retrato del Rey. Lo que estoy señalando es que la indefensión penal del monarca no puede ser concedida sin más, aunque no se utilice el argumento utilizado a veces en el ámbito académico de que a mayor relieve institucional, menor protección penal, que estimo insostenible. También comparto el juicio de inadmisibilidad que el Tribunal ha formulado en relación con la protección penal excesiva de los jefes de Estado, tipificando por ejemplos delitos de lesa majestad, etc. Estoy de acuerdo con Timothy Garton Gash cuando previene contra el mal ejemplo que la protección europea de las figuras políticas supone, pues tiene un efecto deprimente sobre la situación de la libertad de expresión en países no democráticos o iliberales. Creo que la protección penal del monarca es defendible desde el propio derecho europeo si se considera la monarquía como una estructura constitucional, integrante de la identidad nacional, que el ordenamiento europeo protege (art. 4 Tratado de Lisboa). En este orden de cosas, es defendible que el legislador español otorgue una mayor protección cualificada al Jefe del Estado respecto a los demás ciudadanos. Quizás en un orden abstracto no, pues podría pensarse que tal protección es contraria al principio de igualdad. Pero lo que ocurre es que estamos en un orden positivo, el del derecho español, no en un sistema de justicia abstracta construido con criterios meramente racionales. El problema entonces no es de irrazonabilidad sino de congruencia, y desde este punto de vista el delito de injurias agravado sobre la figura del monarca del Código penal (art. 490) se compadece con la condición inviolable del Rey, correspondiente a la imposibilidad del monarca de defenderse por sí mismo en los tribunales. Si el tipo penal es el reverso de la inviolabilidad, mal podríamos suprimir la injuria agravada al monarca respetando la inviolabilidad.

En segundo lugar, lo interesante de la Sentencia es considerar el establecimiento de límites a la libertad de expresión que ella admite, aunque el Tribunal Europeo cree que en el caso concreto que consideramos no jugaban papel alguno, y por tanto no podía aceptarse que la conducta de los demandantes supusiese un caso de abuso de derecho, de acuerdo con el artículo 17 del Convenio, sino un caso de ejercicio plenamente legítimo de la libertad de expresión o de crítica que el Convenio recoge en su artículo 10.

El Tribunal de Estrasburgo establece correctamente como límites de la libertad de expresión la instigación al desorden público y el discurso del odio, considerando que en el supuesto del que se ocupa, esto es, la quema de los retratos de los monarcas en un acto de protesta por su visita a Gerona en el 2007, no nos encontramos ante una incitación a la violencia; ni de otro lado tampoco, frente a lo que consideró el Tribunal Constitucional español, la actuación de los demandantes de amparo cabría ser calificada de discurso de odio.

Que la quema de un retrato es en sí mismo considerada una actuación de extrema violencia, que, además, puede incitar a la continuación de este tipo de proceder a quienes la contemplan parece algo indiscutible, de modo que en estos 
supuestos el orden público corre un grave riesgo que el derecho penal parece llamado a proteger. A mi juicio es secundario que en el caso que nos ocupa efectivamente no tuvieran lugar desórdenes públicos, cuestión que machaconamente subraya la Sentencia que comentamos. Me parece que tampoco cuesta mucho esfuerzo apreciar una diferencia de grado, como muestra de lenguaje simbólico o comunicación de ideas a través de símbolos no lingüísticos, entre la quema de banderas, cuya protección penal debe ceder ante la capacidad expansiva de la libertad de expresión, y la ignición de un retrato de los reyes de España.

Por lo que hace al límite del discurso del odio, que el tribunal juiciosamente reconoce como límite a la libertad de expresión, queda, no obstante, constreñido a las formas de expresión que propagan, incitan, promueven y justifican «el odio racial, la xenofobia, el antisemitismo u otras formas de odio». Más convincentemente la Recomendación n. ${ }^{\circ}$ R (97) del Comité de Ministros del Consejo de Europa incluye en tal concepto de discurso del odio al lenguaje del nacionalismo agresivo y etnocentrista. No es difícil imaginar casos en los que quemar retratos de los reyes ejemplifique un lenguaje de odio nacionalista, que, en una referencia bien inquietante, contempla abusivamente a España como el otro existencial y terminantemente opuesto, a quien, como enemigo público, se menosprecia y abomina.

Los abusos del lenguaje del odio, que puede llevar a la trivialización de su empleo, y a la desprotección de la libertad de expresión, animando a la persecución de un gran número de conductas, que ahora serán condenables, no puede inducirnos a ignorar la justificación de su prohibición, dada la enorme gravedad de la experiencia nazi, y asimismo, en Europa en la actualidad, la peligrosidad de conductas radicalmente contrarias a la bases de la Comunidad Internacional y de la Unión Europea. En ese sentido la persecución del leguaje del odio tiene que ver con el compromiso de diversos organismos, de espectro internacional o europeo, comprometidos en la lucha contra el racismo, la xenofobia y la persecución de minorías étnicas o sexuales. No debe perderse de vista al respecto, que la redacción del artículo 510 del Código penal, que ciertamente, desde un punto de vista técnico, manifiesta los defectos de una legiferación muy criticable, obedece a la trasposición de la Decisión Marco 913 de 2008, «relativa a la lucha contra determinadas formas y manifestaciones de racismo y xenofobia mediante el Derecho penal».

Además, habría que señalar que, precisamente en sintonía con el propósito político pacificador de la persecución del lenguaje del odio, no habría que excluir completar su utilización como instrumento de protección de las minorías vulnerables, admitiendo, como parece permitir la conceptualización llevada a cabo por la Recomendación n. ${ }^{\circ}$ R(97) del Comité de Ministros del Consejo de Europa antes citada, incluir en el discurso del odio, el lenguaje del nacionalismo agresivo y etnocentrista, esto es, casos de nacionalismo de odio. Sin duda estos, como afirma con razón la Sentencia europea contra los precedentes españoles, no se produjeron en los hechos a que se refiere la Sentencia, pero si han podido ocurrir en nuestro país en otras actuaciones en las que la motivación racista y xenófoba es bien patente. 


\section{JOAQUIN URÍAS MARTÍNEZ}

La generalización del uso de internet, independientemente de su futura evolución, ha supuesto ya una revolución en el mundo de la comunicación sólo comparable a la generalización de la imprenta a mediados del siglo Xv. El elemento determinante de esta nueva época es la posibilidad de cualquier ciudadano de dirigirse al conjunto de la sociedad sin la intermediación de una estructura equivalente a las editoriales o los medios de comunicación. La imprenta generalizó la posibilidad de difundir ideas de tal manera que, por primera vez, llegaran prácticamente a toda la sociedad. Internet no sólo ha multiplicado los mensajes disponibles sino que ha democratizado la autoría, permitiendo que cualquiera pueda ver sus opiniones distribuidas por el mundo entero sin necesidad de someterse al filtro de un medio de comunicación.

Esta revolución, sin duda, vendrá a desdibujar la estructura clásica que enmarca el ejercicio de las libertades de expresión e información. Por primera vez las opiniones individuales de cualquiera, desde el instante mismo en que se emiten, tienen impacto potencial en toda la sociedad. En este esquema tan parecido al mercado de las ideas en su concepción liberal originaria, se desdibuja el papel intermediario que solían tener los medios de comunicación de masas y que tiene un importante reflejo tanto en la legislación penal como en la civil. Desaparecen filtros relacionados con la selección de la relevancia pública de las opiniones y la veracidad de las informaciones. El panorama fáctico, por tanto, es diferente al que conocíamos.

Ello no quita un ápice de valor a la libertad de expresión como prius necesario para la realidad misma de los procesos electorales. El pluralismo de voces y opiniones puede complicar los mecanismos de control sobre los discursos que carecen de relevancia social y puede facilitar —en la práctica - la desinformación. Sin embargo, en ese pluralismo y gracias a las posibilidades acrecentadas de diálogo social, la libertad de expresión recupera todo su valor como instrumento para la constitución democrática del poder estatal. Será necesario combatir los posibles efectos perniciosos de la democratización de la distribución de ideas, pero será necesario sin restringir la libertad individual de dar a conocer las ideas propias.

\section{IGNACIO VILLAVERDE MENÉNDEZ}

Desde luego, no me cabe la menor duda. El ciberespacio ha cambiado sustancialmente los medios y el impacto del flujo de contenidos. Ha incrementado la capacidad de difusión y penetración de los mensajes y su influencia en la formación de la opinión pública. En esa medida el ciberespacio está realizando de hecho el ideal democrático de una opinión pública políticamente robusta que madura sus opiniones e ideas en el proceso de comunicación pública al que accede en igualdad de condiciones una ingente cantidad de información de una inmensa 
pluralidad de fuentes. Esta circunstancia, empíricamente comprobable, ha ayudado a reducir la dependencia que tenía el proceso de comunicación pública de las fuentes formalizadas y tradicionales como los medios de comunicación masivos. El acceso a la información es universal y global, y también lo es su flujo. Pero este hecho tiene un reverso oscuro, porque la fiabilidad y confianza que se depositaba en las fuentes de información clásicas se ha visto intensamente debilitada por la circunstancia de que cualquiera puede ser fuente, no hay mecanismos efectivos de discriminación entre fuentes y se ha multiplicado exponencialmente el riesgo de manipulación en la medida en que cualquier fuente puede llegar a cualquier persona sin ningún filtro previo.

2. ¿Qué reflexiones nos quiere hacer sobre el llamado «discurso del odio» y sobre los limites de la libertad de expresión? ¿Considera que la libertad de expresión no debe proteger determinado tipo de discursos?

\section{MARC CARRILLO LÓPEZ}

La primera consideración a hacer ha de partir de una premisa bien sabida: la Constitución no establece un sistema de democracia militante. Los límites a los derechos fundamentales en general y a la libertad de expresión en particular se cifran en el respeto al resto de derechos y libertades. Pero sin que el contenido de la libertad de expresión vaya más allá y sea predeterminado por la Constitución, como por el contrario sí lo hace el artículo 10 del CEDH. De acuerdo con este punto de partida, la principal cuestión de relevancia constitucional que se plantea es el tratamiento tan genérico que le otorga el legislador penal a través de la tipificación del ilícito penal del llamado delito de incitación al odio en el artículo 510.1,a) del CP: «a) Quienes públicamente fomenten, promuevan o inciten directa o indirectamente al odio...». La sucesión en los últimos años de procesos y condenas penales por expresiones divulgadas en medios de comunicación y, particularmente, en las redes digitales ha planteado la cuestión de los límites a la libertad de expresión cuando ésta emplea términos que puedan resultar odiosos, o que empleen el odio como discurso en expresión utilizada por el profesor Miguel Presno, en tanto que puedan resultar hirientes, molestas o inquietantes para determinados sectores de la población.

Vedar en abstracto este tipo de expresiones a través de la represión penal, plantea en primer plano si una social liberal democrática puede consentir este tipo de intervención del Estado frente a opiniones disidentes que se consideren peligrosas para la convivencia y paz social. Porque por esta vía se abren indicios racionales de transgresión del valor constitucional del pluralismo que, en materia de libre expresión en una sociedad abierta, ha de permitir tanto aquellas que manifiesten lo más excelso del pensamiento humano como las que puedan resultar especialmente miserables, pasando por aquellas otras que sean notoriamente 
hirientes. Sea como fuere, en todo caso, el cuerpo social ha de conocerlas, evaluarlas y extraer sus propias conclusiones.

No hay duda de que en el plano particular la Constitución niega la existencia de un derecho al insulto y, por tanto, para la reparación del daño causado en las relaciones inter privatos la legislación civil ofrece soluciones a las intromisiones ilegítimas en los derechos de la personalidad. Por el contrario, la interpretación expansiva del tipo penal del artículo 510.1. a), si a la expresión molesta no acompaña una clara y evidente incitación a la violencia por parte de su autor, hace que la represión penal conduzca casi sin solución de continuidad al Derecho penal enemigo. Por tanto, salvo que medie la violencia, la respuesta penal es profundamente inadecuada.

En relación a los parámetros utilizados por la jurisprudencia comparada para determinar cuándo una expresión puede generar odio, son bien conocidas las posiciones sostenidas por el Tribunal Supremo de los Estados Unidos y por el TEDH de Estrasburgo en Europa. Para el primero, partiendo de su consideración de la libertad de expresión como pilar esencial del sistema democrático y con fundamento en el liberalismo propugnado por Stuart Mill en On Liberty, la libertad de expresión sólo admite restricción cuando sea empleada para incitar a la violencia y genere un peligro claro y evidente. Para el segundo, en cambio, son expresiones propias del discurso del odio las que resulten contrarias a la igualdad y a la dignidad de los grupos minoritarios tradicionalmente discriminados, sin que para ello sea precisa una incitación a la violencia. No obstante, como ha puesto de relieve la profesora Ana Valero, el examen empírico de la aplicación de estos dos criterios por ambas jurisdicciones ha resultado selectivo y en ocasiones incoherente.

A modo de conclusión acerca de este punto, sería mucho más adecuado cuestionar la constitucionalidad del artículo 510.1 a) CP por parte de la jurisdicción ordinaria y de esta forma el Tribunal Constitucional dispondría de una oportunidad para revisar su doctrina al respecto. Hay buenas razones para ello, sobre todo por la abstracción que contiene y los peligros acreditados de una aplicación expansiva, más allá de la interdicción de la discriminación contra grupos vulnerables. Y, a su vez, aceptar como único límite penal a las expresiones odiosas, aquellas que contengan ínsita una clara incitación a la violencia. Esto es, las expresiones que de forma objetiva comporten un riesgo real y efectivo de que se cometa un delito de odio y, por tanto, como recuerda el profesor Bilbao Ubillos, cuando dichas expresiones sean idóneas para generar ese riesgo.

\section{LORETO CORREDOIRA ALFONSO}

Ciertamente me preocupa bastante el nuevo tipo del 510 del Código Penal que recordamos afirma que «1. Serán castigados con una pena de prisión de uno a cuatro años y multa de seis a doce meses: a) Quienes públicamente fomenten, promuevan o inciten directa o indirectamente al odio, hostilidad, discriminación o violencia contra un grupo, una parte del mismo o contra una persona 
determinada por razón de su pertenencia a aquél, por motivos racistas, antisemitas u otros referentes a la ideología, religión o creencias, situación familiar, la pertenencia de sus miembros a una etnia, raza o nación, su origen nacional, su sexo, orientación o identidad sexual, por razones de género, enfermedad o discapacidad. b) Quienes produzcan, elaboren, posean con la finalidad de distribuir, faciliten a terceras personas el acceso, distribuyan, difundan o vendan escritos o cualquier otra clase de material o soportes que por su contenido sean idóneos para fomentar, promover, o incitar directa o indirectamente al odio, hostilidad, discriminación o violencia contra un grupo, una parte del mismo, o contra una persona determinada por razón de su pertenencia a aquél, por motivos racistas, antisemitas u otros referentes a la ideología, religión o creencias, situación familiar, la pertenencia de sus miembros a una etnia, raza o nación, su origen nacional, su sexo, orientación o identidad sexual, por razones de género, enfermedad o discapacidad.c) Públicamente nieguen, trivialicen gravemente o enaltezcan los delitos de genocidio, de lesa humanidad o contra las personas y bienes protegidos en caso de conflicto armado, o enaltezcan a sus autores,» ...

En fin, que leyéndolo en el mundo en que vivimos y con los niveles de libertad de que disponemos, se incluiría casi todo (una serie de Netflix, unos tuits de un anónimo o particular encendido, una columna de opinión en prensa o una clase en la Facultad). Y especialmente este «castigo» sintomático a las Tecnologías (ver abajo apartado 3), o un simple mensaje masivo enviado desde un teléfono inteligente. Lo veo muy desproporcionado y espero que los jueces, como ya ha hecho el Supremo en el caso de la tuitera Cassandra (TS Casación Sentencia núm. 95/2018), archive esos procedimientos.

Ese mismo artículo 510 del Codigo Penal establece que «Las penas previstas en los apartados anteriores se impondrán en su mitad superior cuando los hechos se hubieran llevado a cabo a través de un medio de comunicación social, por medio de internet o mediante el uso de tecnologías de la información, de modo que, aquel se hiciera accesible a un elevado número de personas.»

Como mucho, pienso que debería considerarse un delito similar al de la injuria grave (art. $209 \mathrm{CP}$ ), que NUNCA conlleva penas de privación de libertad.

Comparto con la Fiscalía general del Estado (en su Circular ${ }^{1}$ para interpretar el nuevo tipo), que el eje de ese nuevo delito de «odio», que tampoco pienso que siempre consista en eso, «desde la perspectiva del sujeto pasivo del delito, el eje sobre el que pivota el precepto es la probibición de la discriminación como derecho autónomo derivado del derecho a la igualdad, reconocido en el art. 14 CE, según el cual «los españoles son iguales ante la ley, sin que pueda prevalecer discriminación alguna por razón de nacimiento, raza, sexo, religión, opinión o cualquier otra condición o circunstancia personal o social». La igualdad y la no discriminación se

1 Circular 7/2019, de 14 de mayo, de la Fiscalía General del Estado, sobre pautas para interpretar los delitos de odio tipificados en el artículo 510 del Código Penal (BOE de 24 de mayo de 2019). 
configuran como el presupuesto para el disfrute y ejercicio del resto de derechos fundamentales, como muestra su ubicación sistemática en el pórtico del Capítulo II («De los derechos y libertades»), dentro del Título Primero de nuestra Carta Magna, dedicado a los «Derechos y Deberes Fundamentales».

\section{ÁNGEL RODRÍGUEZ}

A mi modo de ver, la aplicación de restricciones legales al discurso del odio plantea de modo simultáneo al menos tres problemas capitales del régimen jurídico de la libertad de expresión: en primer lugar, la cuestión de la represión penal como instrumento para sancionar los excesos en el ejercicio de este derecho fundamental; en segundo lugar, tal y como se apunta en la formulación de la pregunta, la controvertida aplicación de restricciones a determinados discursos precisamente por su contenido; y, en tercer lugar, la cuestión de la convivencia en Europa de distintos estándares de protección en un escenario multinivel o, mejor, de fragmentación en la protección de derechos fundamentales.

Con respecto a la primera cuestión, que apunta al problema de la tipificación de los denominados «delitos de odio», me remito a lo que al respecto digo en la respuesta a la pregunta cuarta. Con respecto a la segunda, debe recordarse que una aportación clásica de la muy elaborada doctrina norteamericana sobre la primera enmienda a la Constitución Federal es la distinción entre las limitadísimas restricciones que cabe imponer a la libertad de expresión basadas en el contenido del mensaje y las que son, por el contrario, neutrales con respecto a este. Entre las más comunes restricciones que pueden considerarse «content neutral» se encuentran las que regulan las condiciones de tiempo, lugar o modo que se pueden imponer a determinados mensajes para que estén jurídicamente protegidos. Ejemplos conocidos de estas «time, manner and place regulations» son la prohibición de algunos programas en horario infantil o de pancartas ofensivas en eventos deportivos. Desde esa perspectiva, el primer problema que plantea el discurso del odio es que su restricción es necesariamente, «content-based», ya que no pretende proteger determinadas audiencias o excluir determinados mensajes de algunos entornos, sino impedir por completo la difusión de lo que se quiere prohibir: cuando se denuncia un mensaje antisemita, por ejemplo, no se pretende garantizar que al mismo no van a acceder personas de raza judía o que deberíamos ser advertidos de su carácter racista antes de recibirlo, sino que ese mensaje no pueda emitirse en ningún sitio ni bajo ninguna circunstancia.

Como se sabe, en Europa, a diferencia de lo que ocurre en Estados Unidos, las restricciones basadas en el contenido del mensaje han superado el escrutinio de constitucionalidad, por no hablar del de convencionalidad, sin dificultades insalvables. No obstante, dada la radicalidad de una prohibición de ese tipo, deberían extremarse las garantías en su aplicación. En concreto, no debería nunca olvidarse que la prohibición de un mensaje odioso exclusivamente por su 
contenido (más allá por tanto de expresiones que a veces se confunden, aunque integran otros tipos penales como la amenaza o la apología), afecta al núcleo mismo del derecho a la libertad de expresión. Esta libertad, como recordara en su momento el TEDH, protege «no sólo las informaciones o ideas que son favorablemente recibidas o consideradas como inofensivas o indiferentes», sino también aquellas que «chocan, inquietan u ofenden al Estado o a una fracción cualquiera de la población» (STEDH Handyside contra el Reino Unido, de 7 de diciembre de 1976, § 49). Debe insistirse por ello en que su aplicación debe limitarse a aquellos casos en los que se pretenda con esa medida proteger grupos vulnerables y cuando la experiencia histórica haya demostrado que ese discurso es capaz de crear un clima social que incentive la generación de actos discriminatorios o de violencia contra esos colectivos. Por esta razón, en mi opinión, carece de sentido pretender justificar como restricción legítima del discurso del odio mensajes que pueden ofender a grupos o colectivos (no digamos instituciones) que en absoluto se encuentran ni se han encontrado en el pasado en una situación de potencial vulnerabilidad.

Todo ello nos lleva, finalmente, a la cuestión de la diversidad de estándares de protección de la libertad de expresión en el contexto europeo y a las consecuencias que ello tiene en nuestro ordenamiento. Debe tenerse en cuenta que, precisamente por las distintas experiencias que han marcado su historia, las prevenciones contra los mensajes de odio son distintas en los diferentes Estados miembros del Consejo de Europa o de la Unión Europea, que se agrupan a ambos lados de una línea que, grosso modo, distingue los países que se encuentran más allá o más acá de la democracia militante. Como ejemplificó la STC 235/2007 y sus controvertidos efectos sobre el delito de negacionismo, nuestro país se encuentra, aunque cada vez con más matices, en el lado de acá. La diversidad de estándares a la que todo ello conduce se complica aún más, como se sabe, por la concurrencia en Europa de dos normas protectoras de derechos igualmente supranacionales pero con efectos muy distintos, pues uno tiene vocación de estándar mínimo (el de la CEDH) mientras que el otro actúa como un «full standard» dentro de su ámbito (el de la CDFUE).

En definitiva, pocos casos como el de las limitaciones de la libertad de expresión encaminadas a la restricción del discurso del odio ilustran los importantes problemas a los que se enfrenta la teoría de los derechos fundamentales en el momento presente, caracterizado en el orden interno por un derecho constitucional cada vez más líquido y en el europeo por la fragmentación de los mecanismos y niveles de protección.

\section{REMEDIO SÁNCHEZ FÉRRIZ}

Naturalmente, entiendo que la libertad de expresión, como ya he dicho, no puede encubrir todo. Aunque tampoco quepa deducir que lo que no se protege 
por libertad de expresión sea delito: «No todo mensaje inaceptable o que ocasiona el normal rechazo de la inmensa mayoría de la ciudadanía ha de ser tratado como delictivo por el hecho de no hallar cobertura bajo la libertad de expresión» (STS 4/2017, FD $2 .^{\circ}$ ).

Rollnert Liern ha estudiado con detalle la jurisprudencia sobre el discurso del odio y llamado la atención sobre la denominada «zona intermedia» en la que, sin poder invocar la libertad fundamental, tampoco puede incriminarse penalmente: "Conviene recordar que la interpretación más autorizada de los términos utilizados por el art. 20.2 PIDCP para definir la apología del odio punible exige que se trate de un odio cualificado por su intensidad e irracionalidad y que persiga generar en terceros una disposición a actuar, transitando así de un mero estado de ánimo personal a una manifestación activa de hostilidad» (Rollnert, Marcial Pons, 2017). Más recientemente el mismo autor ha hecho una crítica muy seria (a la que me sumo) sobre la interpretación internacional y la jurisprudencia del TEDH por la imprecisión de sus manifestaciones y la falta de una doctrina coherente. La exagerada ampliación del supuesto discurso del odio por el TEDH, más allá de la idea más depurada (o al menos objetiva) de incitación (derivada del art. 20.2 de PIDCP), lleva «indefectiblemente a la incertidumbre que genera un enfoque casuístico que dificulta la estandarización y objetivación de los criterios, especialmente en lo que se refiere a inferir de un cierto contexto la probabilidad de que se produzca el resultado proscrito de violencia, hostilidad o discriminación» (Rollnert, REDC, 2019).

Por mi parte, he de compartir la posición de la Jurisdicción española frente a la del TEDH que la corrigió en el asunto Stern Taulats y Roura Capellera c. España, con resolución de 13/03/2018. Mientras el TC entiende que la quema de bandera y fotos del Rey, con tal forma de expresión, «había desbordado la libertad de expresión hasta suponer una incitación al odio y a la violencia», el de Estrasburgo niega (no se sabe bien porqué) que los manifestantes tuvieran intención de incitar a la violencia pues se trataba solo de una expresión simbólica de desafección y protesta. Desde luego ambas posiciones resultan algo extremas y no acaban de ser satisfactorias; tal vez la razón se halle en los propios hechos que dan origen a la causa pues parece que el llamado «discurso del odio» está pensado más bien para acciones dirigidas frente a grupos raciales, étnicos, religiosos, en las que se supera ampliamente la intolerancia para manifestar desprecio y hasta voluntad de dañar. La complejidad de la cuestión deriva sin duda de que la ley deba regular lo que en realidad no es sino un sentimiento que solo puede incriminarse en sus expresiones exteriores y/o en el daño moral que las mismas puedan producir en terceros.

En este sentido es evidente que resulta mucho más clara la formulación del art. 20.2 del PIDCP («2. Toda apología del odio nacional, racial o religioso que constituya incitación a la discriminación, la hostilidad o la violencia estará prohibida por la ley»), por cierto, al margen de cuanto dispone su art. 19 sobre la libertad de expresión. Por su parte, el art. 10 del CEDH, aunque con algún 
mayor detalle, presenta la estructura y contenido del citado art. 19 que sin duda se inspiró en aquel del año 50, pero carece de un precepto expreso sobre la apología del odio como el 20.2 PIDCP que acabo de transcribir. Pero es obvio que el TEDH podría aplicar la cláusula general de interdicción del abuso de los derechos reconocida en el Art. $17 \mathrm{CEDH}$ : «Ninguna de las disposiciones del presente Convenio podrá ser interpretada en el sentido de que implique para un Estado, grupo o individuo, un derecho cualquiera a dedicarse a una actividad o a realizar un acto tendente a la destrucción de los derechos o libertades reconocidos en el presente Convenio o a limitaciones más amplias de estos derechos o libertades que las previstas en el mismo». Al hacerlo así, el TEDH podría inadmitir no pocos asuntos que, de otro modo, trata de resolver con el art 10 introduciendo una serie de elementos en la interpretación de la libertad de expresión y sus límites que dudo aporten seguridad jurídica ni, desde luego, claridad a la compleja determinación del ámbito de la misma. De este modo deja un «amplio campo al decisionismo judicial casuístico en función del contenido de las expresiones y de un contexto valorado mediante criterios elaborados por acumulación, sin haberlos establecido de forma ordenada y sistemática en aras de la predictibilidad de sus pronunciamientos y de la seguridad jurídica» (Rollnert, REDC, 2019).

Se ha destacado el aumento exponencial de la actividad jurisdiccional sobre los delitos de odio (Tamarit Sumalla, IDP, 2018), sin duda por la facilidad que las nuevas tecnologías proporcionan; pero también se denuncia cierto expansionismo del derecho penal que, a mi juicio, podría reconducirse si existieran vías intermedias entre el derecho fundamental y el delito; creo que la idea de que se comete el delito como intromisión en la libertad de expresión no es la mejor técnica posible y cabría «objetivizar» mejor si se afirmara que en tales casos no se está haciendo uso legítimo de la libertad fundamental. Sin embargo, no es esta la perspectiva de los Altos Tribunales.

\section{JOAQUIN URÍAS MARTÍNEZ}

La doctrina del discurso del odio se sustenta en última instancia en una serie de reflexiones generadas en torno a la llamada paradoja de la democracia; la mayoría parte, sin embargo, de una concepción errónea de la función constitucional de la libertad de expresión como derecho fundamental y de la naturaleza de los mecanismos de control disponibles en manos del Estado.

Desde una perspectiva radicalmente liberal, se acepta de manera acrítica que la sociedad es un libre mercado de ideas en el que todo el mundo puede exponer las propias en igualdad de condiciones y expectativas y, sobre todo, conseguir que sean dominantes. A partir de ello, se alerta sobre los riesgos de que llegaran a alcanzar esa posición preferente opiniones con carácter autoritario o contrarias a los derechos. La conclusión entonces es que la sociedad debe defenderse ante tal riesgo de extensión de ideas potencialmente peligrosas. Esta perspectiva 
tradicional es correcta exclusivamente en la teoría y está alejada de la realidad de los procesos de formación de la opinión pública.

La comunicación pública en realidad viene especialmente determinada por las relaciones sociales de poder, de modo que ni todo el mundo tiene las mismas posibilidades de acceso a los canales de comunicación, ni todas las opiniones son susceptibles de alcanzar el mismo grado de difusión. En los procesos prácticos de construcción del discurso dominante resulta decisiva la participación de los poderes sociales. Se manifiesta en positivo en forma de sostén de los medios de comunicación y sus periodistas, sufragados por poderes económicos. También en el control negativo ejercido por el poder público a través del poder judicial. En este punto es inevitable la interpretación ideológica de los distintos tipos penales o del procedimiento administrativo sancionador.

De este modo, resulta impensable que ningún discurso, ni siquiera el más odioso y contrario a los valores fundamentales, se convierta en dominante sin contar con el apoyo de las instituciones Estatales, notablemente el poder judicial. La experiencia histórica demuestra que los llamados «discursos de odio» sólo han llegado a ser hegemónicos cuando han contado con el respaldo de los poderes económicos, políticos y jurídicos. Así sucedió tanto en la Alemania nazi, como en Ruanda o la antigua Yugoslavia. En ese orden de cosas, las posibilidades de frenar tales manifestaciones mediante prohibiciones penales son ilusorias. El juicio sobre qué ideas o discursos resultan realmente una amenaza a los derechos de las minorías y los valores comunes se realiza sentencia a sentencia. Exige una actividad interpretativa por parte del juez que nunca podrá eximirse de su propia valoración ideológica. El discurso del odio sólo se convierte en dominante cuando tiene el apoyo ideológico del poder judicial que sería, a su vez, el encargado de frenarlo.

Al mismo tiempo, el riesgo de que los delitos de odio se utilicen en la práctica como cobertura para perseguir el discurso disidente es enorme. Para demostrarlo basta echar un vistazo a la jurisprudencia reciente española en la que, en el mejor de los casos, los altos tribunales se ven obligados a revisar conductas por supuesto delito de odio en las que — en ningún modo_ están en juego los valores democráticos o la situación de minorías y colectivos vulnerables, sino la mera discrepancia del juzgador con una línea de expresión. Por si quedara alguna duda, la mayoría de las condenas del TEDH en los últimos años en materia de libertad de expresión se han dictado en casos en los que el Estado había condenado a sus ciudadanos por supuesto delito de odio como cobertura para lesionar su libertad de expresión, disidente de la establecida.

En definitiva, los riesgos de la extensión de la categoría «discurso del odio» en materia de libertad de expresión son mucho mayores que sus hipotéticas e indemostradas ventajas. Conviene, pues, abandonar esta categoría y reducirla a la de «delitos de odios», que no han de relacionarse con la expresión de opiniones ideológica sino con la realización efectiva de conductas discriminatorias. Hay que volver al axioma clásico de que las ideas, incluso las más odiosas, nunca delinquen 
ni causan daño. Perseguir conductas que efectivamente dañan o discriminan y respetar las ideas de cualquier tipo.

\section{IGNACIO VILLAVERDE MENÉNDEZ}

Este es uno de los asuntos capitales de la libertad de expresión en el ciberespacio. El problema no es la existencia del discurso del odio, sino el impacto masivo que ahora tiene a través del ciberespacio y la necesidad de deslindarlo de otro tipo de expresiones. El ciberespacio ha alterado los límites físicos y espaciales que acotaban la circulación de mensajes en el mundo analógico del siglo xx. Como señaló el que fuera juez del TEDH, Sajó, el comentario inapropiado o extremo que se hacía en la barra de un pub y que podía considerarse jurídicamente irrelevante tanto en su contenido y en sus consecuencias porque no trascendía del limitado público que rodeaba en ese concreto instante a su emisor, adquiere una cualidad distinta cuando se propala en las redes sociales, porque ni se sabe quién es su receptor ni las posibles consecuencias de su propagación. La amenaza de muerte que se expresó en la barra de ese pub de forma intrascendente y coloquial, si se hace en las redes sociales puede conllevar resultados muy graves. Con ello no se quiere decir que la incertidumbre sobre los riesgos de las nuevas formas de expresión impone un control de daños que en el ámbito de la libertad de expresión se traduce en la adopción de medidas de censura previa o de severas restricciones a la libertad de expresión en el ciberespacio. No tengo respuesta para cómo mantener el equilibrio entre la decidida protección de la libertad de expresión y las medidas que deben adoptarse para que el ciberespacio no se convierta en un «pozo negro» (Leiter). Creo que ese equilibrio no pasa por desproteger determinados discursos, porque cualquier juicio sobre ellos implica un juicio moral y valorativo de muy difícil justificación en un sistema democrático. Otra cosa es que se sancionen determinados discursos por los efectos que provocan, siempre que se acredite que en efecto los han provocado. Interesante reflexión sería decidir si en esos casos debemos ir, por importar conceptos de la penalística, a un ilícito por peligro abstracto o por peligro concreto.

Es fundamental distinguir además los discursos que pueden provocar esos daños inasumibles en un sistema democrático (y que así lo haya identificado y decidido la ciudadanía a través del procedimiento legislativo correspondiente y por tanto que no resulte de la decisión cuestionable de un juez o un tribunal), de aquellos otros que se limitan a «ofender». El discurso del odio no es el que ofende, sino el que agrede y daña. No existe, por el momento al menos, un derecho a no ser ofendido, pero sí hay un derecho a expresarse, aunque sea para divulgar mensajes inquietantes, molestos o hirientes (TEDH dixit). Cosa distinta es que el principio constitucional del Estado Social nos imponga en las sociedades actuales un deber positivo de protección de ciertos colectivos o minorías frente a determinados «discursos» que las agreden, vejan o discriminen (no simplemente que las 
«ofendan»). En esos casos, puede estar constitucionalmente justificado un estándar de protección de la libertad de expresión más severo y riguroso. Pero en ningún caso una limitación general o una prohibición de un discurso determinado (lo que no deja de ser una forma de censura previa).

3. ¿Cómo valora el hecho de que ciertas expresiones (artísticas, musicales, bumorísticas...) que hace un par de décadas se consideraban ejercicio de la libertad de expresión hoy, sin embargo, no se entiendan protegidas por esta libertad? ¿A qué cree que se pueden deber estos cambios?

\section{MARC CARRILLO LÓPEZ}

Además de la premisa principal que se identifica con el problema de constitucionalidad del artículo 510.1 a) del CP ya señalado y al que es preciso añadir el artículo 525 del CE — sobre el que se volverá más adelante— que tipifica el ilícito penal de la ofensa a los sentimientos religiosos, adicionalmente operan otros factores relacionados con la singularidad que ofrecen para la comunicación las redes sociales.

El potencial acceso universal a las mismas tiene mucho que ver con el incremento del libre flujo de expresiones e informaciones. Como ha señalado el profesor Boix Palop, las redes sociales facilitan mucho más que los medios tradicionales la circulación de la comunicación y el acceso a su contenido, de tal forma que éste puede ser conocido y debatido más intensamente. La comunicación digital y, por tanto, las redes facilitan la propagación de discursos de todo tipo y, según los casos y la coyuntura política y social, la facilidad de acceso a los contenidos más diversos puede espolear el desarrollo de acciones reactivas de sectores sociales que inciten, con razón o sin ella, a la actuación de la policía, la fiscalía o la acción popular. En este sentido, parece evidente que las redes pueden actuar no sólo como una excelente plataforma de expresión sino también como lobby para instrumentalizar conciencias y sentimientos. Como ha quedado acreditado empíricamente por el profesor Boix Palop, muchas de estas actuaciones además de resultar notoriamente desproporcionadas reflejan, asimismo, los problemas derivados del Derecho penal del enemigo, como la arbitrariedad en la persecución penal o el doble rasero de enjuiciamiento de conductas que a la postre resultan análogas, según sea el autor de la expresión artística o humorística que se considera molesta.

El carácter genérico y la abstracción también es imputable al ilícito penal previsto en el artículo 525 del CP que tipifica el delito de ofensa a los sentimientos religiosos, que incluye los comportamientos de escarnio a sus dogmas, creencias, ritos o ceremonias, o vejación pública a quienes los profesan o practican. También resulta ilícita la acción que haga lo propio con respecto a los que no profesan religión o creencia alguna. 
Pues bien, la libertad religiosa es un derecho fundamental que en su dimensión activa comporta la libertad de conciencia, de confesión y de culto; son sus límites el respeto a los otros derechos y aquéllos que resulten estrictamente necesarios para el mantenimiento del orden público. Y en su faceta negativa, significa el derecho o no declarar sobre la propia religión o creencia.

El sentimiento religioso no viene expresamente recogido en la Constitución si bien puede entenderse incluido en la libertad religiosa, como la manifestación íntima y personalísima tanto de creencias trascendentes y a extramuros de la razón, como aquellas otras que rechazan cualquier idea basada en el más allá de la existencia física. No obstante el silencio constitucional, el legislador ha incluido la ofensa a ambos sentimientos como elemento objetivo de un ilícito penal.

Con esta premisa, parece evidente que en un Estado democrático y aconfesional que da cobertura a una sociedad abierta basada en el pluralismo y el respeto a las minorías, el conflicto con la libertad de expresión siempre está abierto sobre las diversas formas de aproximarse a la idea de trascendencia. Como es sabido, un principio básico del Derecho Penal es el de intervención mínima. Por el contrario, la tipificación penal de algo tan difuso y etéreo como son los sentimientos acerca del hecho religioso se sitúa en las antípodas de dicho principio. Al igual que en el discurso del odio, la respuesta penal a las expresiones de crítica o sátira a través de cualquier medio no es adecuada y se ha de descartar. Como sugiere el profesor Pérez Domínguez, la despenalización de este delito sería una consecuencia necesaria en una democracia abierta.

\section{LORETO CORREDOIRA ALFONSO}

En la misma línea de lo dicho, pienso que el cambio en la consideración del alcance que han podido tener exposiciones de arte o fotografía en el pasado se haya visto incrementada por la rápida difusión del mundo en la red. Una foto de IFEMA que adquiere más notoriedad.

Ya ocurrió con el caso de Salman Rusdhie y sus «Versos satánicos en 1988» y no usábamos entonces Internet a nivel general. Más allá de un libro o de unas fotos que puedan exponerse o venderse, lo que se considera «lesivo» al honor, intimidad o sentimientos religiosos es más bien por su carácter público.

Sin duda, en mi opinión, el derecho a la información — terminología que prefiero frente a la «dualidad» de libertad de expresión — incluye ideas, pensamientos y opiniones.

Y las ideas son el ámbito de mayor libertad, por tanto, con menos límites o excepciones, para los que difunden o emiten esos mensajes. Sean los mensajes largos o breves (como un tuit): si hay calumnia la hay por el tipo delictivo del Código Penal en vigor. Y si hay injuria, esta sería grave, si se dan estas circunstancias (de acuerdo con el Artículo 209. Las injurias graves hechas con publicidad 
se castigarán con la pena de multa de seis a catorce meses y, en otro caso, con la de tres a siete meses»).

Y sus excepciones deben ser muy, muy pocas. Eso no significa que se les deba exigir a los medios, a los periodistas, a fotógrafos, etc. respeto a la persona, pero es más un principio ético que una norma obligatoria, que — como es obvioanularía las libertades más básicas de todos.

\section{ÁNGEL RODRÍGUEZ}

Lo valoro como un error. El ámbito de la libertad de expresión no debe circunscribirse a las expresiones clásicas (la palabra o el escrito) o a los canales institucionalizados (la prensa), sino que debe incluir expresiones de muy distinto signo, entre las que sin duda se encuentran las mencionadas en la pregunta, a las que podríamos añadir otras como la prensa «rosa» o «del corazón» o los programas de televisión dedicados al cotilleo, conocidos como «telebasura».

Ahora bien, de ello no debe deducirse que cualquier tipo de expresión deba gozar de los mismos instrumentos de protección. En mi opinión, tan desacertado sería excluir por completo determinadas expresiones del ámbito del derecho fundamental como dispensarles a todas la protección preferente que gozan las expresiones que de forma más directa pretenden incidir en el debate público.

La doctrina de los tres tipos de escrutinios a los que puede someterse un mensaje para dilucidar si merece o no protección por el ordenamiento en función del valor que cabe dar a esas expresiones («high, intermédiate o low value speech») puede ser útil a este respecto. No es la menor de sus ventajas que permite encontrar un punto intermedio entre los que abogan por aplicar siempre los mismos criterios de ponderación a todo tipo de mensajes y los que defienden, por el contrario, que algunos (como por ejemplo la pornografía o, como se comenta en la pregunta sexta el mensaje publicitario) no deben concebirse en ningún caso como ejercicio de la libertad de expresión como derecho fundamental. La principal ventaja de esa clasificación tripartita de los mensajes a efectos de su protección constitucional sería pues que, gracias a la existencia de categorías intermedias, se le podría proporcionar a los tribunales una herramienta para dispensar a determinados tipos de mensajes alguna protección jurídica, sin alejarlos por completo del campo de la libertad de expresión, aunque acercándolos a la «strict liability» que se aplica en algunas jurisdicciones a los tipos de mensajes que gozan de escasa protección constitucional.

El principal resultado de todo ello sería, pues, no desterrar por completo este tipo de mensajes de la protección que debe dispensarles el art. $20 \mathrm{CE}$, aunque no falten entre nosotros partidarios de esa solución. La consecuencia jurídica de su calificación como expresiones de menor valor sería igualmente importante, pero huiría de una distinción tajante, «polar», entre mensajes que merecen protección por suponer un ejercicio de la libertad de expresión y otros que no la merecerían en absoluto por situarse fuera del ámbito de este derecho. 


\section{REMEDIO SÁNCHEZ FÉRRIZ}

En general, sí se consideran incluidas o, mejor dicho, son especialidad de la libertad de expresión determinada por el ámbito de la creatividad. La cuestión es si dicha creatividad, que con frecuencia puede llegar a exceder los límites del buen gusto, podría también seguir invocando la protección constitucional cuando además supera límites de lo aceptable en una sociedad plural en cuanto invada bienes jurídicos protegidos como, pongo por caso, la protección de la infancia y la juventud. No sé si ha cambiado la jurisprudencia o han cambiado los usos sociales, la intensidad y estilo de las creaciones artísticas. Observo un grandísimo trecho entre el aval constitucional otorgado a un libro (STC 51/2008, de 14 de abril, caso Editorial Santillana, S. A.) que contenía algún dato «privado» sobre la juventud de algún político socialista muy conocido y los twits repetitivos que se juzgan hoy conteniendo canciones ofensivas (ej. el reciente caso sobre «La insurgencia», SAN 34/2017, de 4 dic.).

Si consideramos la extraordinaria amplitud y potencialidad que los soportes informativos han experimentado en las últimas décadas, no debería extrañarnos que a un potencial mucho mayor con que se cuenta hoy para mostrar todo tipo de ideas y opiniones se corresponda en proporcionalidad con la inquietud por preservar los valores y bienes constitucionales que, no tan «sobre situados» como la expresión en las nuevas tecnologías, deben seguir siendo defendidos. Creo por ello que debemos releer el art. 20 en su conjunto y reflexionar, de nuevo, a la vista de las nuevas realidades sociales y tecnológicas.

Volviendo a la concreta cuestión, llama mucho la atención que se ignore la libertad reconocida en la letra c del pfo 1 del art. 20 CE (Se reconoce el derecho....»A la producción y creación literaria, artística, científica y técnica») que, si bien es cierto queda vinculada a la «matriz» de expresión, resulta algo más precisa (o desprovista de la expansividad de la libertad de expresión) y, por tanto, permitiría un examen algo menos «relativo» o «diluido» como los que observamos en la jurisprudencia de los Altos Tribunales en torno a la libertad de expresión. Un ejemplo de lo que digo creo que podemos contrastarlo en el ya mencionado caso de «la insurgencia».

También sorprende la obsolescencia (o al menos silencio en casos tan conflictivos como los de referencia) del art. 20 en su pfo. 4: «Estas libertades tienen su límite en el respeto a los derechos reconocidos en este Título, en los preceptos de las leyes que lo desarrollen y, especialmente, en el derecho al honor, a la intimidad, a la propia imagen y a la protección de la juventud y de la infancia». De las dos cláusulas de especialidad que en él se contienen (protección de los derechos del art. 18.1 y defensa de jóvenes y niños) podría entenderse el silencio sobre la primera puesto que tiene su propia regulación y defensa en los asuntos en que se ven afectados. Pero no así la segunda mención que se ignora generalmente en asuntos en que, por no ser directa e inmediatamente afectados (ni por consiguiente parte en los respectivos procesos judiciales), nunca suelen ser objeto de consideración olvidando que hoy la adolescencia nutre mucho más la conformación de su pensamiento en las redes sociales que en la vida real. 


\section{JOAQUIN URÍAS MARTÍNEZ}

La extensión del espacio para la crítica disponible en una sociedad está directamente relacionada con el grado de debate realmente existente en ella. En las sociedades homogéneas culturalmente en las que no se ponen en duda determinados valores sustanciales resulta más difícil aceptar el necesario espacio para la crítica. En nuestra sociedad actual, pese a la pluralidad de voces y la facilidad de acceso a la opinión ajena, se está instaurando un convencimiento sobre la intangibilidad de determinados valores y principios a los que se quiere hacer, además, inmunes a la crítica.

Uno de los ejemplos más relevantes es el del espacio que socialmente se atribuye al ejercicio de la libertad a la creación artística. La esencia de este derecho fundamental está en la absoluta libertad sustancial para la creación de mundos imaginarios, elaborados ex novo, que no son una representación exacta de la realidad pero que se nutren de ella. Estas creaciones tienen la virtualidad de provocar en el receptor una reflexión sobre el mundo real, generada desde su sublimación. En términos jurídicos tales creaciones difícilmente tienen capacidad de generar daños sobre otros derechos porque no pretenden reflejar la realidad sino simplemente evocarla. Así, la publicación de una novela como obra de ficción - al contrario de lo que sucede en un artículo informativo o un libro de memorias- tiene escasa capacidad de incidencia sobre las personas que se vean reflejadas en alguno de los personajes.

Al situarse fuera del plano de la realidad, el derecho a la creación artística ha tenido tradicionalmente un amplio margen de desarrollo en el que las presuntas afecciones sobre otros bienes jurídicos difícilmente se concretaban. El proceso social al que estamos asistiendo, sin embargo, se caracteriza por una creciente conciencia de que el concepto de daños morales cubre la sensación de indignación o molestia que puede sentir el ciudadano que ve publicadas ideas contrarias a las suyas.

Se trata de una extensión peligrosa en la medida en que desplaza el sentido de la afección de los derechos propios al terreno del debate de ideas, de tal manera que quien ve rebatida las suyas de manera molesta o irritante reivindica por ello una lesión de derechos propios. Esta conciencia de que en el debate público no tienen cabida todas las opiniones se aplica especialmente a las expresiones artísticas y, entre ellas, a las que pretendan ser sorpresivas, heterodoxas o chocantes. Se plasma jurídicamente en el ámbito del derecho penal en una interpretación extensiva de los tipos penales, que ahora pasan a cubrir situaciones en las que no se daña la esfera privada de los particulares sino su expectativa de no ver combatidas sus ideas de un modo desagradable.

Así, por ejemplo, se llegan a calificar de amenazas y sancionar como tal, expresiones musicales expresadas en el tono desabrido propio de músicas de protesta como el rap que no en ningún momento aluden a la posibilidad real de causar ningún daño a sus destinatarios. Se trata, en este mismo ejemplo, de expresiones 
metafóricas y exageradas que pueden hablar del deseo de que una bomba nuclear aplaste a un representante político. Evidentemente, la operación de trasladar literalmente lo que sólo pretende ser metafórico al terreno de la realidad es una disfunción constitucional, en cuanto aplica a la ficción imaginaria las normas pensadas para regular el mundo de la realidad.

En este sentido, resulta cada vez más importante — en aras del pluralismoreivindicar las características propias del derecho a la creación artística y recuperar la diferencia entre el mundo de las ideas - en el que todas las opciones han de ser permisibles-y el de la aplicación práctica, en el que se generan las conductas lesivas de derechos, ajenas a la libertad de expresión.

\section{IGNACIO VILLAVERDE MENÉNDEZ}

La respuesta a esta pregunta enlaza directamente con lo contestado a lo anterior. La sanción, frecuentemente penal, de determinados mensajes tiene mucho que ver con la hipersensibilización a cierto tipo de contenidos. El desbordamiento de los límites físicos y espaciales que limitaban el proceso de comunicación pública analógico explica la especial atención que ahora tienen estos discursos y por tanto la en ciertos casos sobredimensión de sus consecuencias ofensivas para ciertos colectivos o minorías. Añádase a ello que suelen ser decisiones judiciales las que han provocado esta discutible evolución en el tratamiento de ciertos discursos sin un respaldo legal indiscutibles y por tanto sin que haya sido el conjunto de los ciudadanos a través de sus representantes políticos los que hayan decidido limitar (que no es sinónimo de negar) la libertad de expresión para proteger determinados valores o colectivos o minorías.

Muchas de estas decisiones carecen de respaldo constitucional porque constituyen negaciones de la libertad de expresión sustentadas en la hipotética protección de un inexistente derecho a no ser ofendido de colectividades más o menos difusas y sin apoyo legislativo claro alguno. Odiar es libertad de expresión, pero hacer odiosos puede que no. No porque no sea libertad de expresión, que también lo es, sino porque está limitada por el derecho de otros a no ser odiados y a sufrir en consecuencia el daño que conlleva tener esa condición. Como ha llamado la atención muy pertinentemente Presno, hay que distinguir entre el odio como discurso, que en principio estaría protegido por la libertad de expresión (y no exento de sufrir también sus límites constitucionales, desde luego), del discurso del odio donde el odio sí puede ser un delito en determinadas circunstancias.

4. Recientemente el TEDH ha considerado que una condena penal impuesta por España era contraria a la libertad de expresión ¿Cree que sería conveniente algún tipo de reforma respecto a los limites penales de esta libertad? 


\section{MARC CARRILLO LÓPEZ}

Esta decisión tomada por el TEDH en su sentencia de 13 de marzo de 2018 en el asunto Stern Taulats y Roura Capellera era perfectamente previsible, teniendo en cuenta, entre otros, los precedentes judiciales que también afectaron a España (Castells) en 1992 y (Otegui Mondragón) en 2011. En este este sentido, conocida la jurisprudencia de Estrasburgo sobre el alcance de la crítica a las instituciones y aquellos que las representan (Jefes de Estado, Primeros ministros, etc.), reflejada, entre otros, en los casos Handyside (1976) y Lingens (1986), la STC 177/2015 decidida por una ajustada mayoría frente a cuatro votos particulares resultó especialmente desafortunada. Entre otras razones, porque en el pasado el propio Tribunal la había asumido, en un caso en el que el titular de la Corona también había sido el destinatario de una crítica no precisamente amable (STC 20/1990, Caso "Juanjo Fernández y las críticas al Rey»).

En términos jurídicos la consideración de sentencia desafortunada se sustenta en la desorbitada concepción del delito de odio, que el Tribunal empleó para enjuiciar el conflicto con la libertad de expresión en un caso de presuntas injurias a la Corona con motivo de la quema de una foto del Rey en Girona. Y no ha sido un caso aislado. En los últimos tiempos ha cobrado carta de naturaleza la tendencia a desnaturalizar o mejor, como recuerda el profesor Bilbao Ubillos, a banalizar el discurso del odio o también del delito de enaltecimiento del terrorismo.

Esta vis expansiva otorgada al discurso del odio supone una puerta abierta a criminalizar las expresiones disidentes cuando éstas adoptan formas que resultan disfuncionales para lo que entiende como parámetro asumible por la mayoría del cuerpo social. Insertar en el ilícito penal del delito de odio las expresiones molestas, duras, hirientes o similares, significa hacer abstracción del alcance que permite definir el elemento objetivo de este tipo penal, que no es otro que la protección de las minorías sociales frente expresiones y actos discriminatorios por razones de sexo, raza, etnia, nacionalidad, etc.

Por otra parte, es evidente que en algunos casos este tipo de expresiones pueden resultar perfectamente punibles por la vía del delito de injurias o calumnias, lo cual es obviamente distinto. Por ello, la instrumentalización interpretativa del delito de odio en el sentido expansivo señalado conduce, cuando se trata de una crítica exacerbada a las instituciones, a introducir por la puerta de atrás elementos propios de una democracia militante.

En este sentido, tomando como ejemplo el caso de las críticas la Corona, debería reconsiderarse el mantenimiento del delito de injurias al Rey (art. 490.3 $\mathrm{CP})$. Fuera de la valoración que pueda merecer su actuación en el ejercicio de las funciones públicas que le están constitucionalmente atribuidas, la protección de los derechos de la personalidad del Jefe del Estado frente a cualquier intromisión, en tanto que particular y al igual que corresponde a cualquier otra persona, está prevista en el conjunto del ordenamiento jurídico tanto civil como penal. 


\section{LORETO CORREDOIRA ALFONSO}

Estamos en un momento en que los Tribunales internacionales están discutiendo derechos o leyes nacionales y es parte del modelo político elegido. Firmado un Tratado internacional, aceptamos su jurisdicción. La jurisprudencia del TEDH ha sido tan amplia, en casos como el cierre del diario EGIN, las fotos del Rey, o esta que comentan, que permite sacar dos conclusiones: falta aún rodaje, y mejora en la doctrina iusinformativa.

Por lo que ya he comentado en estas páginas, sí veo excesivo el control penal de los «llamados» discursos del odio que encubren censura.

\section{ÁNGEL RODRÍGUEZ}

Como todas las libertades públicas, y a diferencia de otras categorías de derechos fundamentales, la libertad de expresión puede ejercerse de modo abusivo, lo que legitima al Estado para que, respetando las debidas garantías, sancione a los que así actúan. Es incluso posible que, si el abuso de derecho se comete bajo determinadas circunstancias, el Estado pueda poner en marcha el ius puniendi. Ahora bien, el derecho penal debe en esta materia mantenerse como última ratio y, fiel al principio de intervención mínima, reservarse sólo para los ataques más dañinos a los bienes jurídicos más importantes.

En el caso de la libertad de expresión, además, debe ponerse de relieve que deben preferirse otras vías distintas de la represión penal. No es casualidad que la protección civil de los derechos que más frecuentemente colisionan con la libertad de expresión no se regulara en nuestro país hasta después del franquismo, con la aprobación de la LO 1/1982: para la dictadura, la represión penal era el modo habitual de proceder contra las expresiones cuyo contenido entrar en conflicto cualquier bien jurídico digno de protección.

Aunque nuestro Tribunal Constitucional no haya formulado una regla clara exigiendo que, como un elemento más de la posición preferencial de la libertad de expresión, esta se limite por normas civiles antes que por las penales, sí existen pronunciamientos que se aproximan a este principio. No sólo ello. Es muy posible que una de las implicaciones de la exigencia preferente de vías no penales para corregir los abusos de la libertad de expresión sea que, allí donde esas vías no tienen cabida, no sea jurídicamente posible restringir el mensaje. Es decir, en los casos en los que el único instrumento con el que cuente el Estado para reaccionar frente a un ejercicio pretendidamente abusivo de la libertad de expresión fuera el derecho penal, nos encontraríamos pues ante supuestos que en puridad no deberían ser susceptibles de restricción: cuando quepa la vía civil, debería preferirse a la penal, reservándose esta para supuestos excepcionales; cuando no quepa, no debería admitirse restricción alguna.

Ese sería el caso, por ejemplo, de las sanciones por delitos cometidos al proferir expresiones frente a las cuales, dada la naturaleza del bien jurídico 
protegido, no podrían ponerse en marcha mecanismos de carácter civil para dispensarles protección. Se trata, en general, de expresiones que ofenden al Estado, sus símbolos o instituciones, que no deberían poder ser sujetos pasivos de un procedimiento como el de la $\mathrm{LO}$ 1/82, tanto por razones procesales como sustantivas, pues los poderes públicos deberían carecer del derecho al honor, sin que ello sea óbice para que se pueda extender su titularidad a otras personas jurídicas. Sería esta la otra cara de la moneda del principio de que los poderes públicos no son tampoco titulares del derecho a la libertad de expresión: por idénticas razones, no podrían ser titulares de derechos de la personalidad directamente vinculados a la dignidad humana.

Todo ello debería llevar al legislador no ya a reformular, sino simplemente a eliminar, delitos como el de ultraje a España o a las Comunidades Autónomas, o el de usar la imagen del Rey u otros miembros de la Familia Real de cualquier forma que pueda dañar el prestigio de la Corona, dejando pues sin sanción algunas expresiones no verbales como la quema de banderas, de efigies o retratos o cualquier otro símbolo político.

\section{REMEDIO SÁNCHEZ FÉRRIZ}

Debe aclararse, de entrada, que la vía penal nunca ha estado bien vista para resolver las cuestiones en que se invoca la libertad de expresión. Tal vez en el tercero de los casos que mencionaré (caso Jimenez Los Santos) pudo haber sido otra la solución de haber resuelto los Tribunales nacionales en la vía civil. Pero no cabe olvidar que en este caso se responde a una querella interpuesta por el ofendido. En los otros casos es lógica la aplicación de la vía penal y justamente es propio de una sociedad democrática que no exista vía administrativa, aunque recientemente se ha introducido alguna previsión que pone de relieve la incoherencia entre la amplísima protección a la libertad de expresión y algunas decisiones administrativas que contrastan con las tan citadas del TEDH. No creo que las resoluciones de la Comisión Nacional de los Mercados y la Competencia, de 31 mayo y 13 sept., ambas de 2018 (en aplicación del art. 4.2 de la Ley 7/2010 de 31 de marzo, General de comunicación audiovisual) resistan la más mínima revisión judicial.

Ya he manifestado cierta disconformidad con decisiones del TEDH. En ocasiones tengo la impresión de que un Tribunal que juzga en torno a decenas de ordenamientos podría caer en la máxima romana ya aludida (lo que prueba demasiado no prueba nada). Sin duda nuestro ordenamiento requiere de muchas reformas, pero tengo mis dudas que esa sea ni la más urgente ni la más pertinente. Desde luego si se pretendiera hacer una reforma la cosa no acabaría en los límites de la libertad de expresión sino en otros muchos principios del ordenamiento jurídico que se ven afectados por las tan repetidas necesidades de la sociedad democrática. 
Pienso en los casos más recientes: Toranzo Gómez c. España (26922/14), de 20/11/2018 o en Stern Taulats y Roura Capellera c. España (51168/15 y 51186/15), de 13/03/2018. Tal vez estaría bien que el Tribunal europeo explicara a los miembros de la policía judicial como hacer para sacar a quienes (tras el largo proceso que supone todo desahucio, cualesquiera que sean los intereses de terceros si los hay) se han embutido (en forma imposible de salir) en una estructura de hormigón. De paso, podría también explicar lo importantísimo que es quemar imágenes o emblemas en una sociedad democrática que se supone que ha de velar por la educación y formación de los menores (por ejemplo); concluye el TEDH en este segundo caso que, al fin y al cabo, no es un caso aislado sino que es uno más en una serie de actuaciones para manifestar el rechazo ( «la incitación a la violencia, dice la sentencia, no puede deducirse del examen conjunto de los «decorados» (sic) utilizados para escenificar el acto...»). ¿Afirma que como ya es frecuente pasa a ser normal?

Faltan tal vez en el segundo referentes ordinamentales más concretos pues no cabe ignorar que nuestra Constitución, y por supuesto el Convenio de Roma, se sostienen en valores y este último más aún que nuestra constitución al establecer claros límites al ejercicio de las libertades públicas en el segundo párrafo de los artículos que las reconocen. En el caso del art. 10 no puede ser más claro: «El ejercicio de estas libertades, que entrañan deberes y responsabilidades, podrá ser sometido a ciertas formalidades, condiciones, restricciones o sanciones previstas por la ley...». La ley no puede limitar todo aquello que sea necesario en una sociedad democrática, por supuesto, pero la cuestión me parece discutible, repito, si estamos dando a los jóvenes imágenes tan «ejemplares» (¿?) y supuestamente »democráticas». Como he dicho «supra» sobre nuestro art. $20 \mathrm{CE}$, tal vez no estaría de más detenernos a reflexionar cuál era la sociedad democrática a que se aspiraba en 1950 al redactar el Convenio y evaluar su aplicación en la actual.

Cuestión distinta, y de más fácil resolución por ser de clara la contraposición entre libertad de expresión y honor de una persona, es el caso Jiménez Losantos c. España (53421/10), de 14/06/2016. De nuevo subrayaría la improcedencia o «exceso» de la via penal en el TEDH que recurre al principio de proporcionalidad para contradecir al TC español.

\section{JOAQUIN URÍAS MARTÍNEZ}

La regulación de los delitos de opinión en nuestro código penal ha obedecido históricamente a una lógica exclusivamente penal, hasta el punto de que gran parte de las bases de su ordenación tiene carácter previo a la Constitución. La incorporación de los derechos fundamentales al código penal se ha hecho a posteriori, sobre todo modulando los elementos del tipo conforme a la jurisprudencia del Tribunal Constitucional. Este modo de operar implica que las categorías penales básicas no siempre están construidas de manera coherente con la configuración de los derechos y libertades constitucionalmente protegidos. 
En el ámbito específico de la libertad de expresión esto lleva a que algunos tipos penales necesiten de una interpretación conforme por parte de los jueces para adaptarlos al reconocimiento constitucional de los derechos del artículo 20 CE. En estos momentos, nuestro ordenamiento penal recoge un buen número de ejemplos de esto. A modo de ejemplo baste citar los delitos de ofensas a la corona, ofensas a los sentimientos religiosos o enaltecimiento del terrorismo entre otros muchos. Aparecen formulados de una manera amplia que prácticamente puede entenderse como una invitación a limitar el ejercicio de estos derechos fundamentales. La reforma más urgente, en estos casos, es la de la descripción de las conductas perseguidas que debe perfilarse de tal manera que ningún tribunal pueda entender que incluyen la mera expresión de ideas, la creación artística o la difusión de hechos noticiosos en los términos definidos por la jurisprudencia constitucional.

No sólo es necesario reformar el tenor literal de diversos tipos penales sino, más allá, aclarar las bases ideales en las que se desenvuelve la relación entre derechos fundamentales y conductas delictivas. Los derechos fundamentales son algo más que una causa de exclusión de la responsabilidad penal. Idealmente, la descripción de las conductas castigadas en los tipos penales debe realizarse excluyendo las que supongan el ejercicio de un derecho fundamental, de tal manera que nunca se produzca la aparente antinomia de que una conducta aparezca como prohibida por el código penal al mismo tiempo que la Constitución proteja su ejercicio como derecho fundamental. Hay que superar de una vez por todas la concepción de que el ejercicio de un derecho fundamental excluye la acción penal. Esta proposición transmite la idea de que corresponde al juez, excepcionalmente, dejar impune por mandato constitucional unos hechos que, a priori, habría que castigar. De lo que se trata es de que el propio tipo penal no incluya en su descripción de la conducta perseguida actos que constituyan el ejercicio de un derecho fundamental.

En definitiva, resulta errónea la idea misma de límites penales a la libertad de expresión. Los límites a los derechos no puede establecerlos un juez. Bien al contrario, los derechos funcionan como límite de la acción de los poderes públicos, incluido el legislador.

\section{IGNACIO VILLAVERDE MENÉNDEZ}

No, en términos generales, salvo quizá los delitos de injurias a instituciones públicas. La Sentencia del TEDH en el caso Stern Taulats y Roura Capallera apunta claramente en esa dirección. Sin embargo, opino que el problema no es tanto el diseño de los tipos penales limitativos de la libertad de expresión, como la forma en la que en los últimos tiempos la jurisprudencia los ha interpretado y aplicado. La tendencia ha sido a considerar no protegidos por la libertad de expresión ciertos tipos de discursos por considerarlos «objetivamente» odiosos, cayendo 
las más de las veces en una ponderación de bienes y valores con un muy discutible sustento constitucional. Es muy difícil justificar en nuestro sistema constitucional que la quema de la foto del Jefe del Estado es un «discurso» no protegido ni por el artículo 16 ni por el artículo $20 \mathrm{CE}$ cuando no está en juego ningún derecho fundamental de un tercero, y tampoco ningún bien constitucional que resulte evidente. Cualquier limitación penal a un derecho fundamental es sumamente controvertida y debe sustentarse en una indubitada protección de derechos o bienes constitucionales en situaciones de extrema gravedad. No hacerlo así es simplemente hacer «derecho penal del enemigo» (Jacobs).

5. La jurisprudencia del Tribunal Constitucional sobre las libertades de expresión e información se ha centrado, sobre todo, en el conflicto entre estas y los derechos de la personalidad ¿Qué valoración general le merece dicha jurisprudencia?

\section{MARC CARRILLO LÓPEZ}

La jurisprudencia construida a lo largo de los cuarenta años de vigencia de la Constitución para resolver la colisión entre los derechos fundamentales reconocidos en el artículo 20.1, a) y d) y el articulo 18.1 permite sostener que ha establecido unas serie de reglas interpretativas que, en general, garantizan las libertades de expresión e información como pilar esencial del sistema democrático y los derechos de la personalidad, como presupuesto básico de la libre autodeterminación de la persona en la sociedad abierta.

En apretada síntesis, entre otros, estos criterios interpretativos se han traducido en: 1) la necesidad de distinguir entre la libertad de expresión y el derecho a comunicar y recibir información veraz se define, en el primer caso, por la existencia de elementos valorativos; y en el segundo, por la relevancia de factores de naturaleza fáctica que integran el objeto de la información, aunque sea obvio que la línea divisoria entre hechos y opiniones no siempre es nítida y ello exija la ponderación judicial para determinar el elemento prevalente. 2) La consideración del derecho a la información como una especie de primus inter pares respecto de los derechos de la personalidad, siempre que por razones objetivas resulte de interés general y los hechos sean noticiables; o bien cuando la información se refiera a personas que por su dimensión pública, determinada por el cargo que ocupan, la función representativa que ejercen (personajes públicos) o la actividad profesional que habitualmente desarrollan (personajes de notoriedad pública), también resulten de interés general. 3) La preeminencia de la libertad de expresión y derecho a la información respecto de los derechos de la personalidad cuando se proyecten sobre derechos de personas de relevancia pública, no comporta que éstas carezcan de los derechos de la personalidad fuera del escenario público que ocupan. 4) La crítica a las instituciones públicas y a aquellos que temporalmente las 
representan es una lógica consecuencia de la libertad ideológica y el pluralismo político, aun cuando las opiniones resulten hirientes, molestas o desabridas. 5) La veracidad en la información es un límite constitucional que ha de ser entendido en términos relativos, no absolutos; así, gozará de protección constitucional aquella información que haya sido elaborada y difundida con diligencia deontológica y buena fe profesional, incluso en los casos en los que hayan podido incurrir en error. 6) La veracidad informativa no siempre exculpa de responsabilidad: la veracidad no legitima la injuria. No existe un derecho al insulto. 7) La relevancia jurídica del mandato constitucional de la veracidad informativa no es la misma cuando se enfrenta al derecho al honor que cuando afecta al derecho a la intimidad. En principio, la veracidad funciona como causa legitimadora de las intromisiones en el derecho al honor, mientras que su relevancia puede ser distinta si afecta a la intimidad: en este caso, la intromisión será legítima solo si se justifica en función de su interés público. 8) La doctrina del reportaje neutral exime de responsabilidad al medio de comunicación que se limita a reproducir declaraciones o afirmaciones de terceros que puedan ser lesivas de los derechos de la personalidad. Pero esta exención decaerá si el medio de comunicación no puede acreditar la identidad del sujeto autor de dichas declaraciones.

Seguramente, la jurisprudencia sobre el derecho a la intimidad es la que ha experimentado cambios importantes respecto del alcance de este derecho. En sus inicios el Tribunal sostuvo un criterio material para definir el ámbito del derecho a la intimidad sujeto a protección (por ejemplo, la 159/2009). Esta línea interpretativa se fundó en la doctrina alemana de delimitar la intimidad en diversas áreas de la vida de la persona en las que la intromisión de terceros quedaba impedida: tanto en el ámbito espacial (el cuerpo, la salud, la vida sexual, el ámbito familiar etc.,) como frente a los medios de comunicación. A fin de cubrir las lagunas que presentaba la concepción material al dejar en un segundo plano la propia concepción del interesado sobre su ámbito privado, a finales de la década de los noventa la jurisprudencia experimentó un giro importante en favor de un criterio formal de la intimidad, destinado a atribuir prevalencia a la posición de la persona respecto del alcance de su propia intimidad (por todas, la STC 144/1999). Sin embargo, no es seguro que este criterio impida el peligro maximalista del subjetivismo de la persona afectada y el creacionismo interpretativo de algunos jueces.

No hay duda de que la protección del ámbito íntimo de una persona le ha de ser garantizado en cuanto como titular del derecho el sujeto, a fin de que pueda decidir sobre qué aspectos de su vida privada impide el acceso a terceros. Y, ciertamente, ello ha de ser así, en principio, con independencia de su contenido; sea éste objetivamente íntimo o banal. El derecho a la intimidad ha de permitir dejar extramuros del conocimiento público, tanto lo que para el titular pueda ser importante como, por supuesto, también lo que sea perfectamente inocuo; o lo que sea verdad como también aquello otro que sea una falsedad. Pero un planteamiento de este tenor no puede hacer abstracción de una realidad obvia e 
intangible: que el titular del derecho es un sujeto que, aunque desee ser un ermitaño, el entorno social que lo circunda pueda no resultar indiferente tanto a lo que haga o diga como a sus acciones y a sus omisiones. Y, por tanto, que, en su caso, ello pueda resultar de interés público y transcienda a su legítima voluntad de pasar desapercibido.

Por esta razón, la concepción subjetiva del derecho a la intimidad llevada a ciertos extremos puede conllevar el riesgo de caer en excesos, en demérito del derecho fundamental a comunicar información veraz como pilar esencial e insoslayable de una sociedad democrática. Porque, desde el momento en el que se exacerbe el protagonismo de la persona en la delimitación absoluta de los contornos de su intimidad, como ha señalado el profesor Manuel Medina, pierden pie todas aquellas consideraciones acerca de la relevancia de los datos divulgados.

De acuerdo con lo expuesto, y a fin de mantener un ponderado equilibrio entre los derechos del artículo 18.1 CE y del artículo. 20.1 CE, parece preferible, no tanto mantener el enfoque material tradicional sino, más bien, procurar la necesaria complementariedad entre la concepción material y formal del derecho a la intimidad, que retenga la interrelación entre el contenido de lo divulgado y la capacidad de decisión del titular de derecho, en el contexto en el que la intimidad y la intromisión informativa se manifiestan.

En otro orden de temas de interés jurisprudencial, la doctrina del Tribunal Constitucional deberá encontrar nuevas oportunidades para perfilar mejor la interpretación del conflicto entre los derechos de los artículos 20. a) y d) y 18 CE en relación a temas tan dispares como, por ejemplo, el derecho a honor de las personas jurídicas; el derecho al olvido digital, el derecho a una expectativa de intimidad frente al uso de las cámaras ocultas, el uso del correo electrónico en el ámbito laboral, etc.

\section{LORETO CORREDOIRA ALFONSO}

Pues cambiante, también al hilo de los tiempos, y necesaria para ir fijando qué ampara y qué no el art. 20 de la Constitución.

\section{ÁNGEL RODRÍGUEZ}

En mi opinión, los derechos fundamentales al honor, a la intimidad y a la propia imagen establecidos por la Constitución Española (CE) se encuentran satisfactoriamente protegidos en nuestro ordenamiento, con la muy notable excepción de los efectos que los denominados «juicios paralelos» tienen sobre el derecho al honor del que es titular una persona acusada de haber cometido un delito pero que aún conserva intacto su derecho a la presunción de inocencia, lo 
que me he permitido llamar en otro lugar «derecho a la reputación de inocencia».

El origen de esta deficiente protección del honor de los inocentes podría encontrarse en el modo como se elaboró en nuestro país la doctrina jurisprudencial que otorgó a la libertad de expresión un lugar central como base del propio sistema democrático. En sus años fundacionales, el TC se inclinó más por el modelo norteamericano que por otros modelos europeos que, tanto en países de common law como en países de derecho civil continental, despliegan una protección más eficaz de los derechos de las personas sometidas a investigación o enjuiciamiento. Sin embargo, la «importación» del modelo norteamericano no fue completa en nuestro país, ya que la jurisprudencia constitucional sobre la posición preferente de la información y la opinión aparecida en los medios sobre asuntos sub iudice no se vio complementada por una regulación eficiente de los límites a la libertad de expresión de las partes en los procedimientos judiciales, las autoridades policiales y judiciales, sus agentes y el resto de coadyuvantes que participan en la administración de justicia.

Como se sabe, junto con la del Tribunal Supremo de los Estados Unidos, la mayor influencia en la jurisprudencia del TC sobre la libertad de expresión ha provenido del TEDH. Sin embargo, la recepción en nuestro país de la doctrina del TEDH no ha tenido suficientemente en cuenta que el derecho al honor no está directamente protegido por la CEDH y que tanto éste, tal como se encuentra establecido por la CE, como el derecho a la presunción de inocencia (éste sí contemplado tanto por la CE como por la CEDH), deben gozar en nuestro país de la protección constitucional y no sólo de la convencional cuando ésta última sea menos intensa que la que prescribe el ordenamiento interno.

En mi opinión, las transformaciones actuales del principio de publicidad procesal exigen que la información y las opiniones sobre asuntos sometidos a enjuiciamiento o a investigación policial o judicial no se rodeen siempre de los mismos privilegios que la información o las opiniones que versan sobre otros asuntos públicos. Sin menoscabar la relevancia para el interés general que pueden encerrar los asuntos sub iudice (empleando este término en un sentido amplio), a la posición preferente de la libertad de expresión cuando se ejerce sobre los mismos deberían aplicársele límites más estrictos que los que se aplican a las noticias sobre el resto de asuntos de interés general. En particular, no debería atribuirse una protección preferente a los actos que pudieran calificarse de «defensa mediática» que, por el contrario, deberían catalogarse como modalidades del ejercicio forense de la libertad de expresión, sujeta por ello a un régimen jurídico específico, en el que deberían incluirse también las relaciones con los medios de comunicación de todos los que están directamente implicados en los procesos judiciales. Tampoco deberían gozar de una posición preferencial los mensajes susceptibles de ser catalogados de «info-entretenimiento judicial», cuya protección por el ordenamiento debería partir de su escaso valor para la configuración de una opinión pública libre. 
Pero la necesidad de abordar desde nuevos postulados el fenómeno de los juicios paralelos no se limita a los casos de ejercicio extralimitado o abusivo de la libertad de expresión. La tensión entre los derechos del justiciable y el ejercicio de la libertad de expresión sobre asuntos judiciales se da de manera permanente, con carácter estructural. Está presente igualmente en las informaciones solventes y en las opiniones en las que es perceptible el interés general que se derivaría de su contribución a una opinión pública libre sobre un asunto de tanta trascendencia como es el funcionamiento de la administración de justicia. Estas expresiones deberían gozar, en principio, de una protección preferencial por el ordenamiento, pero, debido a la especial caracterización de los asuntos sub iudice, su posición preferente debería, al mismo tiempo, ser objeto de una especial modulación.

La primera de esas modulaciones afectaría, introduciendo matices de importancia, al principio en virtud del cual queda protegida la información falsa pero diligente sobre asuntos de relevancia para la opinión pública. Un recto entendimiento de la información diligente debería condicionar la capacidad discrecional de los medios para ofrecer información parcial sobre asuntos sub iudice. Esta concepción de la diligencia reduciría significativamente el uso que en estas materias podría hacer la prensa de la técnica del «reportaje neutral».

En segundo lugar, y con el mismo planteamiento, debería fortalecerse en nuestro ordenamiento el despliegue del secreto sumarial externo (es decir, no para las partes), fundamentándolo exclusivamente en la protección de los derechos de las personas investigadas y sometiéndolo a una declaración expresa de secreto por parte de la autoridad judicial, que podría encontrar acomodo en la doctrina ya establecida por el TC al respecto. El secreto externo debería respetar siempre el principio de proporcionalidad y vincularía también a los medios de comunicación. Podría afectar al menos, durante algunas fases de la investigación, al resultado de diligencias que supongan una invasión formal en la intimidad de los investigados (como las intervenciones en sus comunicaciones o los registros en sus domicilios), a sus antecedentes penales o policiales y, en determinadas circunstancias, a su propia identidad personal.

Argumentos análogos podrían aplicarse para defender una distinta ponderación de la libertad de opinión cuando ésta se ejerce en asuntos relacionados con la administración de justicia. Tampoco aquí resulta satisfactoria la aplicación en exclusiva de la doctrina según la cual las opiniones sobre asuntos de interés general sólo tienen como límites las expresiones vejatorias o insultantes que no son necesarias para el mensaje que se pretende transmitir. En el caso de asuntos sub iudice, por el contrario, hay juicios de valor que pueden haberse emitido sin emplear expresiones vejatorias o insultantes y cuyo conocimiento puede no considerarse ajeno al interés de la opinión pública, pero que no deberían encontrarse, pese a ello, jurídicamente protegidos. Se trataría de todas las opiniones que pusieran incontrovertiblemente por culpable a los que aún no han sido declarados como tales por la autoridad judicial, lesionando de este modo el derecho a la reputación de inocencia de los aludidos. 


\section{REMEDIO SÁNCHEZ FÉRRIZ}

La opinión ha de ser positiva en la medida en que es el TC el que ha trazado los criterios delimitadores no solo de las libertades informativas con los derechos del art. 18.1 CE sino también los que distinguen una y otra de tales libertades con consecuencias jurídicas bien diversas según cuál de las dos se invoque (Sánchez Ferriz, Tirant, 2004). Así mismo y en particular sobre la libertad de expresión, el TC ha consolidado la idea de su reforzamiento cuando la misma constituye un soporte de otras libertades y derechos como, por ejemplo, libertad sindical (STC 127/2018, de 26 de noviembre de 2018, entre otras que resuelven el mismo supuesto de hecho), o derecho de defensa ejercido por los letrados.

Al publicarse la Constitución el art. 20. 4 pareció excesivo a quienes nos dedicábamos a estas reflexiones hasta el punto de pensar que debía considerarse como «no puesto». Sin embargo, llama la atención que haya sido tan ninguneado en casos como los aludidos supra. Incluso en el conflicto entre los arts. 18.1 y 20.1 ,a) se ha observado en ocasiones algún exceso en la estimación de la «preferencia democrática» de la $2 .^{a}$ disposición sobre la $1 .{ }^{a}$. No obstante, no cabe negar que pese a alguna contradicción pasada con el tiempo se han ido reajustando ambas disposiciones y configurando una doctrina más que aceptable incluso en los casos más delicados (como los de las cámaras ocultas). La recientísima sentencia TC 25/2019, de 25 de febrero, (Thomas Erich Hertlein contra Antena 3) sintetiza dicha jurisprudencia y completa la doctrina asentada desde la STC 12/2012 sobre la regla general de ilegitimidad de la obtención de imágenes a través de cámara oculta. Considero de interés la distinción que lleva a cabo el F. j. 4 entre los tres derechos del art 18.1, pues aun siendo ahora clara no siempre ha sido coherente ni convincente la doctrina del TC, ni tampoco ha tratado de distinguir intimidad y vida privada que solo muy recientemente plantea (tácitamente, al menos). El F. j. 9 lleva a cabo una cuidada distinción de las razones jurídicas que permiten considerar ilegitima la obtención de la información por cámara oculta desde las diferentes perspectivas de los tres derechos implicados (honor, imagen e intimidad) y aporta respecto del derecho a la información alguna manifestación cuyo interés debo subrayar porque creo debería constituir un nuevo criterio de resolución de conflictos:

«No debe confundirse, en efecto, el interés general de un debate en abstracto con la relevancia pública de la concreta información divulgada; ni la curiosidad alimentada por el medio de comunicación, al atribuir un valor noticioso a la publicación de las imágenes objeto de controversia, debe ser confundida con un interés público digno de protección constitucional... Bajo el pretexto de realizar una denuncia o contribuir a un debate general no se puede dirigir la atención del público a una persona que hasta ese momento carecía de notoriedad...» (F.j.9).

Creo que este tipo de precisiones resulta determinante para seguir delimitando correctamente los derechos en conflicto y más aún hoy que son tantos los medios y redes sociales que pueden generar debates y hasta noticias no siempre 
avalados por la realidad social ni por las necesidades y/o preocupaciones ciudadanas.

En concreto sobre el derecho a la información creo que la doctrina está mucho más depurada. Una muy reciente sentencia del TC (la 24/2019, de 25 de febrero, por denuncia en periódico digital de los cobros ilícitos de una Presidenta de Diputación) lo demuestra, especialmente en su F.j. 5 y en el fallo en que ampara al periodista por el uso legítimo del derecho del art. 20.1,d) CE.

\section{JOAQUIN URÍAS MARTÍNEZ}

La jurisprudencia de nuestro Tribunal Constitucional ha sido esencial para el asentamiento de los derechos fundamentales en el ordenamiento español. En ese sentido, más allá de vacilaciones ocasionales, es un instrumento importantísimo para asegurar la eficacia de los derechos y conseguir que, razonablemente, impregnen todo el ordenamiento.

Sin embargo, lo cierto es que esta jurisprudencia adolece a veces de falta de altura o, mejor dicho, de pretensiones de permanencia y generalidad. El sentido objetivo del recurso de amparo no debe proyectarse sólo en la fase de admisibilidad de los recursos de amparo, sino que debe tener también un reflejo en las decisiones elaboradas con conciencia de su valor didáctico y su incidencia sobre el ordenamiento.

En la materia a la que ahora nos referimos hay que resaltar la gran diferencia que hay entre la jurisprudencia relativa a la libertad de información y la de la expresión. La primera ha venido a delimitar cada vez con más precisión el ámbito protegido por el derecho fundamental. Así se ha consolidado la idea de que la información constitucionalmente protegida debe ser veraz en el sentido de estar contrastada con diligencia profesional y tener relevancia pública. Sobe la veracidad se ha ahondado incluso en el grado de contraste necesario según se trate de declaraciones ajenas (reportaje neutral) o incluso de fuentes oficiales o fiables. Adicionalmente, se exige que la información no contenga insultos y, en ocasiones, que haya sido obtenida legítimamente, si bien este último requisito está aún en fase de construcción doctrinal. Con esta tarea de delimitación, el Tribunal Constitucional ha contribuido a incrementar la seguridad jurídica, aclarando con un grado alto de certeza los supuestos en los que cabe ejercer el derecho fundamental con una razonable expectativa de quedar protegido por la Constitución.

Esta doctrina contrasta enormemente con la dedicada a la libertad de expresión. En casi cuarenta años de jurisprudencia, el Tribunal Constitucional aún no ha proporcionado una definición más o menos operativa de lo que sea la libertad de expresión. En este sentido, parece que sigue anclado en la teoría del «coche escoba», conforme a la cual este derecho puede amparar en principio cualquier forma de expresión pública. La doctrina constitucional en este punto ha sido incapaz de identificar con cierta claridad cuáles son las ideas cuya difusión quiere 
asegurar la Constitución, confundiendo el vehículo de expresión con su contenido. Lo que define a la expresión constitucionalmente protegida no es el uso de la palabra, la imagen u otro modo de transmitir ideas, sino el valor público de lo expresado. Sin embargo, esta construcción no aparece aún de manera clara en la jurisprudencia constitucional sobre el asunto. Por ello, tampoco hay declaraciones operativas sobre el contenido protegido del derecho. Quizás la declaración más trascendente en este sentido sea la que hace la STC 235/2009 en el sentido de que la mera difusión de ideas nunca puede ser perseguida.

Junto a esto, es evidente que muy a menudo las decisiones constitucionales sobre libertad de expresión se construyen desde una perspectiva del conflicto de derechos que no puede sino laminar su eficacia jurídica directa. En materia de libertad de información el planteamiento del supuesto conflicto sí esconde una concepción normativa de los derechos fundamentales. La construcción de los requisitos de la libre información se ha hecho a partir de la delimitación de otros derechos. Así, el requisito de la veracidad de la información encaja con la idea de que el derecho al honor protege frente a descensos inmerecidos en la reputación ajena, que son inmerecidos por ser inveraces. Así, una información veraz no puede en principio lesionar el honor, de modo que la delimitación de los derechos facilita la resolución de los supuestos conflictos sin necesidad de recurrir a ponderación alguna. Lo mismo sucede con la relevancia pública de la información, que parece excluir la legitimidad de informaciones que al versar sobre la vida privada puedan venir prohibidas por la garantía de la intimidad. Sin embargo, en materia de libertad de expresión, respecto a la que no se ha procedido a este necesario deslinde, se opera sin criterios claros de tal manera que se cercena la seguridad jurídica dando la impresión de que dependerá de cada juez apreciar la gravedad o el interés de unas declaraciones y dotarlas o no de protección constitucional. En este punto, pues, la jurisprudencia está en ocasiones negando la eficacia misma de los derechos fundamentales.

\section{IGNACIO VILLAVERDE MENÉNDEZ}

La jurisprudencia del TC ha atravesado distintas etapas y ha ido madurando sus criterios y parámetros a golpe de caso concreto. A la fecha de hoy puede afirmarse que nuestro TC posee un cuerpo de doctrina solvente en esta materia y con criterios afianzados que además se han adecuado y están alineados, en términos generales, con la doctrina del TEDH.

No obstante, en los últimos tiempos el TC ha desfallecido en el sostenimiento de ese cuerpo de doctrina. En primer lugar, porque ha caído en cierta resolución rutinaria de los casos con una aplicación en ocasiones automática de los criterios sin reparar en aspectos particulares del caso que lo podrían hacer singular. Lo curioso en estos casos es que se alcanzan resoluciones que son contradictorias con lo que realmente resultaría de la estricta aplicación de la doctrina del 
propio TC (el caso antes citado del TEDH y que trae su causa de la STC 177/2015 es un buen ejemplo). En segundo lugar, el sistema de admisión de los amparos instaurado tras la reforma de 2007 de la LOTC ha convertido en insólitas las sentencias en esta materia, lo que ha acentuado la sensación de que el TC resuelve casuísticamente y de forma errática. Y en tercer y último lugar, el TC ha vuelto al empleo de la técnica ponderativa para resolver este tipo de casos. Todo ello termina por dibujar un paisaje poco favorable para una comprensión avanzada y profunda de la libertad de expresión y su convivencia con otros derechos constitucionales.

6. Como ha ocurrido con otros derechos fundamentales, el ámbito de protección de la libertad de expresión se ha ido ampliando para entender incluidas actividades nuevas, como, por ejemplo, la publicidad ¿Qué opinión le merece esta tendencia en general, y en concreto en el caso de la libertad de expresión?

\section{MARC CARRILLO LÓPEZ}

Que la publicidad es una manifestación más donde se manifiestan la libertad de expresión y el derecho a la información no constituye una novedad. De hecho, la libertad de expresión de las personas jurídicas está especialmente vinculada con la publicidad comercial. Aunque, desde luego, no de forma exclusiva, porque nada impide que una corporación privada pueda emitir su parecer sobre temas de interés general o sectorial más diverso. Es sabido que la jurisprudencia constitucional española no ha llegado todavía a establecer una doctrina al respecto acerca de la titularidad de las personas jurídicas. Pero es difícil que ello pueda excluirse. Porque en el ejercicio de la libertad de empresa en el marco de la economía de mercado, la publicidad comercial también está presente la libertad de expresión.

El Derecho y la jurisprudencia comparada, por ejemplo, tanto en los Estados Unidos como en Alemania, y desde luego en las decisiones del TEDH y del TJUE los ejemplos son muy frecuentes al respecto. Sin ir más lejos, desde hace ya mucho tiempo España fue condenada por el TEDH en un caso referido a la relación entre publicidad y libertad de expresión de abogados (STEDH de 24/2/1994, caso Casado Coca).

En todo caso, es evidente que la intensidad de los límites que operan sobre la libertad de expresión cuando ésta se proyecta sobre la publicidad comercial puede ser más intensos, en función de los derechos fundamentales y bienes jurídicos que entran en juego y que pueden llegar a colisionar, cuando la dinámica de la libre competencia de los diversos actores los enfrenta en el mercado. Como recuerda el profesor RUBÍ PUIG, entre esos límites se pueden identificar los que se derivan de la publicidad sexista, la publicidad de medicamentos que requieren 
de prescripción médica para su comercialización, la interpretación de la cláusula general de deslealtad en el mercado y las restricciones al emplazamiento de productos. En estos casos, la defensa de la libertad de expresión no se fundamenta tanto en la garantía de opinión pública libre como en la salvaguarda de derechos y libertades respecto de los cuales determinados contenidos publicitarios pueden resultar especialmente agresivos para personas o grupos.

\section{LORETO CORREDOIRA ALFONSO}

Me parece básico que consideremos la publicidad dentro del art. 20 de la Constitución. Eso hemos defendido los que nos dedicamos al Derecho de la Información o Comunicación, y es un modo y medio más de expresión.

\section{ÁNGEL RODRÍGUEZ}

Se trata, creo, de un fenómeno en cierta medida inverso al que se ha comentado en la pregunta tercera. Por las mismas razones que la exclusión de la libertad de expresión de los mensajes que allí se mencionaban me parecían un error, considero ahora afortunada la inclusión en su ámbito del mensaje publicitario.

Lo cierto es que el régimen jurídico de la publicidad ha estado durante mucho tiempo, y hasta fechas relativamente recientes, ajeno a una reflexión doctrinal de conjunto que lo aborde desde un punto de vista constitucional. La falta de atención por la doctrina constitucionalista se ha ido colmando poco a poco en la mayoría de los países europeos, y antes en Estados Unidos, desde el interés suscitado por el primer leading case sobre la cuestión del Tribunal Supremo, Virginia State Pharmacy Board contra Virginia Citizens Consumer Council 425 U.S. 748, un asunto del año 1976. En esta línea jurisprudencial, creo que es ineludible concluir que la libertad de expresión protege también la publicidad. Ahora bien, a esta modalidad de libertad de expresión se le debe poder aplicar un estándar de protección menor que el de los mensajes que, por su naturaleza política, se consideran merecedores de la más alta protección constitucional. También en este sentido se ha pronunciado, como se sabe, la jurisprudencia del TEDH, a partir de la STEDH Casado Coca contra España, de 24 de febrero de 1994.

Deben distinguirse, pues, dos planos distintos en el debate en relación con el régimen jurídico del mensaje publicitario, que pueden diferenciarse también por el distinto grado de consenso doctrinal que rodean los argumentos manejados en cada uno de ellos: en cuanto al primer plano, poca discusión suscita hoy en día la tesis de que la publicidad se incluye dentro del ámbito protegido por la libertad de expresión. En cuanto al segundo, es decir, el debate sobre los fundamentos para dispensar a la publicidad, aun reconociéndola como modalidad de la libertad 
de expresión, una menor protección constitucional, el consenso doctrinal es menor.

La cuestión gira fundamentalmente, como se sabe, en torno al papel que debe jugar en la definición del régimen jurídico de la publicidad, junto con la libertad de expresión, la libertad de empresa. En líneas generales, puede decirse que mientras más se acerque a esta última, más amplio será el margen que pueda concederse al legislador para limitar, o incluso prohibir, la actividad publicitaria, y ello como consecuencia de la menor fortaleza que presenta frente a este la libertad de empresa (art. 38 CE) en relación con la libertad de expresión (art. 20 CE).

Los interrogantes aún abiertos sobre el régimen constitucional de la publicidad deberían dirimirse, creo, en la línea de una mayor posibilidad de regulación del mensaje publicitario (pudiendo llegar en determinadas circunstancias incluso a su prohibición), si bien cuidando siempre de no lesionar los contenidos esenciales, como se ha dicho de intensidad distinta en cada caso, de los dos derechos fundamentales en presencia.

\section{REMEDIO SÁNCHEZ FÉRRIZ}

La ampliación de todo eventual ejercicio de los derechos fundamentales ha de merecer, en principio una opinión positiva. Sin embargo, no creo que sea buena decisión incluir la publicidad en ninguna de las dos libertades informativas.

Ciertamente, la amplitud del ámbito de la libertad de expresión es tal que cabría defender que la publicidad es un modo de expresar ideas, pensamientos u opiniones. Incluso, apurando más la cuestión también podría considerarse objeto del derecho a la información aquella publicidad que contenga información veraz de relevancia pública como por ejemplo seria la publicidad electoral y en especial la institucional así como la publicidad parlamentaria o de otras instituciones vinculadas al deber de transparencia (recientemente he defendido en este sentido la vinculación del deber de transparencia a la fundamentalidad del derecho a la información, Sanchez Ferriz, Corts, 2018). Pero salvo algún caso como el mencionado, las dos libertades que el art. 20 reconoce, y su fundamentalidad, nada deberían tener que ver con la publicidad comercial, farmacéutica, etc. ni de concretos partidos o grupos sociales o políticos.

Recuerdo siempre que el prof. Desantes decía que las libertades informativas se dirigían a la razón (al cerebro) y la publicidad a otros órganos vinculados con el instinto y los impulsos. Creo que es bien gráfica la distinción. Pero me gustaría, además, recordar nuestro marco constitucional e, incluso, en relación con dicho marco, nuestro sistema de civil law, al que no siempre le cuadran las importaciones anglosajonas, como en otras ocasiones ya he expuesto, en particular, sobre la importada doctrina de la prefferent position. Haré una breve consideración sobre ambos aspectos: 
1. Nuestra Constitución distingue perfectamente tres niveles de derechos (vid art. 53) que se imbricarían innecesariamente en una interpretación como aquella a la que alude la pregunta. Y creo que las dudas son más que las respuestas ¿han de ser orgánicas las leyes sobre publicidad? ¿hemos de considerar fundamental el derecho de propiedad y de libertad de empresa (arts. 33 y 38) que se hallan en la base de la publicidad comercial?, etc.

Creo que una adecuada precisión de lo que sean derechos fundamentales y libertades públicas, de su ámbito, finalidad y estructura, no habría perjudicado en absoluto el buen funcionamiento del complejo ordenamiento jurídico español. El mismo cuenta con multitud de instrumentos de protección que parecen minusvalorarse, en este caso los de la publicidad, así como sus límites (entre los que, obviamente, se hallarían los derechos fundamentales) si no pasan el filtro del Tribunal Constitucional. Siempre he creído que un buen entendimiento de lo dicho habría evitado la sobrecarga del TC y la necesidad de la reforma de 2007 cuya filosofía ya era bien clara en el buen entendimiento del título I de la Constitución.

2. En cuanto a la segunda: sin duda la primera enmienda americana y nuestro reconocimiento constitucional de las libertades públicas (arts. 19 a $28 \mathrm{CE}$ ) son una buena representación de dos sistemas de difícil homologación y con efectos francamente distintos sobre el papel del poder judicial en uno y otro. Es cierto que la tradicional contraposición entre ambos se ha suavizado con el tiempo, pero no puede, sin más ignorarse. Creo que en ello tiene influencia negativa la actuación del TEDH cuyas decisiones se aplauden por ser suyas sin que nos detengamos a reflexionar si son, o no, coherentes con nuestro ordenamiento constitucional.

Confio en que lo aludido en estas dos reflexiones permita explicar la improcedencia de la introducción de la publicidad en el ámbito de la libertad de expresión, innecesaria según he dicho ya y muestra, una más, de la falta de claridad en el adecuado entendimiento de nuestros derechos fundamentales que son los que son y no todos los del Título I ni todos los que se le ocurran a algún Alto Tribunal cuando este aplica otro ordenamiento jurídico. Me llama la atención que quienes defienden la (tácita) fundamentalidad de la publicidad se amparan en algunos principios rectores del Cáp. III del Título I (el interés económico del empresario, el interés del consumidor y el interés público en que haya información en los intercambios comerciales...) cuando justamente, a mi juicio, se trata de bienes jurídicos que limitarían su libre uso y no, como se pretende, fundamentos de tan privilegiada posición.

\section{JOAQUIN URÍAS MARTIINEZ}

Nuestro ordenamiento jurídico carece de una noción clara de libertad de expresión. Es una carencia de la que la academia tiene gran parte de culpa. A 
pesar del rigor técnico de los distintos apartados del art. 20.1 CE en materia de libertad de expresión seguimos operando con categorías decimonónicas. Por encima de todas ellas destaca la falsa idea de la libertad de expresión como un principio genérico, de escasa virtualidad normativa, que cubre todos los actos comunicativos posibles.

Es cierto que esta comprensión se alimenta de la traslación inmediata de la jurisprudencia del Tribunal Europeo de Derechos Humanos a nuestro ordenamiento. Esa traslación olvida a menudo, sin embargo, las diferencias esenciales entre el sistema europeo de protección de derechos humanos y el régimen de los derechos fundamentales españoles. El sistema europeo es un sistema de mínimos que debe ser aplicable a Estados con realidades jurídicas muy diversas. Parte del tenor de los artículos del Convenio, técnicamente muy diferentes a las normas constitucionales españolas, y opera con categorías como el margen de apreciación o la posibilidad de restringir los derechos —entendidos como principios - por las necesidades de una sociedad democrática. Así, la jurisprudencia del TEDH debe servir como marco delimitador del funcionamiento del derecho estatal pero resulta del todo inapropiado trasladar los métodos de operar de ese Tribunal al derecho español. Del mismo modo, carece también de lógica jurídica —y resulta perjudicial para la eficacia de los derechos fundamentales - la tendencia a convertir en nivel máximo de protección lo que no es sino el límite máximo de restricción permitido en el ámbito europeo.

Estas reflexiones vienen especialmente a cuento a propósito de la cuestión sobre la protección constitucional de los mensajes publicitarios al amparo de la garantía de la libertad de expresión. Desde un concepto estricto y normativo de los derechos fundamentales los mensajes publicitarios destinados exclusivamente a persuadir al receptor de que adquiera un determinado bien o un servicio no pueden ser considerados ejercicio de la libertad de expresión. Ninguno de los apartados del artículo 20.1 CE da cobertura a este tipo de actos. No hay en España una garantía genérica de la comunicación interpersonal, que tampoco tendría ningún sentido constitucional. La libertad de expresión del art. 20.1.a) CE no protege la actividad de expresarse en público, sino la transmisión de ideas con relevancia pública. Es decir, que quedan fuera de la protección constitucional los actos comunicativos que respondan a una intención diferente a la de transmitir el posicionamiento de su autor sobre cuestiones de trascendencia para la sociedad. Utilizar la palabra u otra vía de comunicación para insultar, amenazar o persuadir de una adquisición no puede ser libertad de expresión, pues ésta consiste en expresar posicionamientos ideales personales.

La tendencia a considerar que los anuncios publicitarios son una manifestación de la libertad de expresión parte de un entendimiento de ésta como principio genérico que puede amparar cualquier conducta comunicativa en vez de como una norma de eficacia directa. Los defensores de esta posición se excusan en que hay sentencias del TEDH que así lo han entendido. Frente a ello, la comprensión más adecuada para la plena eficacia de los derechos fundamentales sería la de 
aceptar que los mensajes publicitarios pueden eventualmente llegar a constituir un ejercicio de la libertad de expresión, cuando se emitan con la intención de dar a conocer un posicionamiento ideológico del emisor. Así, si una organización ecologista contrata espacios publicitarios para difundir su posición sobre los peligros que amenazan al medio ambiente, sería libertad de expresión. Si lo que el anuncio pretende es vender un detergente, no lo sería. El ejemplo más claro se da con la publicidad electoral: cuando busca exclusivamente conseguir el voto es un acto político con trascendencia para el ejercicio del derecho de participación política (art. 23.1 CE), pero es susceptible de ser prohibido en determinadas circunstancias como antes de la campaña electoral. Cuando, en cambio, sólo busca transmitir la posición política de una formación es un ejercicio de la libertad de expresión que no puede ser proscrita, aunque su ejercicio deba someterse a la regulación legal.

Una construcción normativamente vinculante de la libertad de expresión no puede operar incluyendo o no nuevas categorías en la definición del derecho, sino delimitando ésta de una manera universal que permita subsumir en ella a cualquier actividad que reúna los requisitos constitucionalmente exigidos.

\section{IGNACIO VILLAVERDE MENÉNDEZ}

Es una evolución lógica ligada a los cambios sufridos en los modos de comunicación. En todo caso, en referencia a la publicidad, sigue existiendo cierta disputa dogmática sobre qué publicidad es la amparada en la libertad de expresión. No parece que se haya aceptado, al menos en España, la doctrina norteamericana que considera protegida por la I Enmienda cualquier clase de mensaje publicitario. En Europa parece más bien que se otorga esa protección sólo a la publicidad que dé soporte o forma a la transmisión de una idea, información u opinión, y no a la que se limita a presentar un determinado producto.

La lógica de la libertad de expresión es la divulgación de pensamientos e informaciones para mantener exento de coacciones el proceso público de comunicación entre las personas. Que cada cual diga o informe de lo que quiera y como quiera, ese es el objeto de la libertad de expresión. En unos sistemas la protección puede centrarse más en el proceso comunicativo mismo (como el español) y en otros lo hace en el mensaje (como el alemán). En los primeros es más sencillo que la publicidad esté amparada por la libertad de expresión que en los segundos. Pero en cualquier caso la garantía constitucional debe extenderse a toda forma de comunicación pública.

7. ¿Cómo valora el uso del principio de proporcionalidad para determinar si, en caso concreto, una determinada actividad está protegida por la libertad de expresión? ¿Cree que una mejor delimitación del ámbito protegido y/o una recuperación del 
concepto de contenido esencial podrían ayudar a resolver con mayor seguridad los conflictos relativos al ejercicio de esta libertad?

\section{MARC CARRILLO LÓPEZ}

La respuesta a esta cuestión viene prefigurada con las consideraciones realizadas anteriormente en la quinta pregunta con respecto a la colisión entre los derechos del artículo 20.1.a) y el derecho a la intimidad.

Como ha puesto de relieve el profesor Ignacio Villaverde la jurisprudencia constitucional ha definido la libertad de expresión por sus límites. Más allá de la muy acertada definición que de la misma hizo la célebre STC 6/1981 ya evocada en la primera respuesta, en realidad la jurisprudencia constitucional sobre este derecho fundamental ha sido muy tributaria del resultado del examen de la ponderación y del consiguiente juicio de proporcionalidad acerca de la colisión con otros derechos fundamentales — en especial, los derechos de la personalidad-y bienes jurídicos protegidos, como la moral o el cumplimento de las obligaciones contenidas en los contratos de trabajo.

De forma constante y hasta a finales de los noventa, el Tribunal recurrió a esta regla hermenéutica para resolver los recursos de amparo presentados contra resoluciones de la jurisdicción ordinaria en la que el demandante cuestionaba la forma en la que el juez y/o el tribunal ordinario la había aplicado. Las más de las veces, haciendo caso omiso o desconociendo la jurisprudencia constitucional que les vincula sobre los derechos en conflicto y en relaciones jurídicas interprivatos, con lo cual, como subraya Villaverde, la cuestión que jurídicamente se dirimía se centraba en el terreno del derecho a la tutela judicial, y no el contenido de los derechos enfrentados.

La consecuencia de este planteamiento ha sido que, al girar la interpretación en torno a la proporcionalidad de los límites a la libertad de expresión, efectivamente, se descuidaba el examen más profundo de los mismos fundamentado en el contenido material de los derechos en colisión. Y, por tanto, aparecía el riesgo de abrir en exceso la espita del creacionismo o al activismo judicial tendente a trasladar a la resolución judicial una indeseable carga de subjetividad. Y ello siempre es problemático para la seguridad jurídica si, como no puede ser ignorado en España, se produce en el contexto de una judicatura que, sin perjuicio de la excelencia jurídica que pueden acreditar una parte de los jueces que la integran, el vigente sistema de selección por el turno libre de oposición no excluye la posibilidad de otros jueces tendentes a reflejar en sus decisiones posiciones metajurídicas que en ocasiones rayan el despropósito.

A partir de la STC 200/1998 ha variado la forma de afrontar los conflictos de la libertad de expresión/información con otros derechos fundamentales, de acuerdo con una previa determinación del contenido constitucional de los derechos enfrentados para ulteriormente llevar a cabo un juicio de ponderación a fin de decidir 
sobre la razonabilidad de los límites a la libertad. En este sentido, los criterios que antes se han resumido en la respuesta a la quinta pregunta permiten acotar mejor el concepto de contenido esencial, tarea de por sí nada fácil: es decir, interés público de la expresión/información, sea por su objeto o por la posición que la persona destinataria de la misma ocupa en el escenario público, reglas sobre la veracidad en la información, aportación al debate en una sociedad democrática, etc.

\section{LORETO CORREDOIRA ALFONSO}

Creo que la solución, de nuevo, y sin ser demasiado positivista, es ir a lo esencial. Me gusta mucho la idea de que desarrollemos qué es el «contenido esencial» del art. 53 de la CE ya que, si desposeemos a un derecho de comunicar esto, expresar lo otro, incluso la rabia, o el desacuerdo, o limitar un medio porque su alcance es universal, desnudamos al derecho a la información de sus esencias, de modo que se hace irreconocible.

\section{ÁNGEL RODRÍGUEZ}

Para determinar los límites del principio de proporcionalidad aplicado a las restricciones a la libertad de expresión podría ser útil comenzar por las reflexiones que se han hecho en Estados Unidos sobre el uso de la técnica de la ponderación («balancing») por parte del Tribunal Supremo cuando se encuentra en juego el ejercicio de un derecho protegido por la primera enmienda a la Constitución Federal.

La doctrina norteamericana ha distinguido entre dos tipos de «balancing» en relación con la libertad de expresión: el que se encuentra ya condicionado por la caracterización previa del caso como uno en el que el mensaje deberá merecer o no la protección completa de la primera enmienda («principled balancing») y el que se emprende directamente, sin una previa consideración acerca de si existe o no una posición preferencial de las expresiones enjuiciadas antes de descender a las circunstancias ( «ad hoc balancing»). Las diferencias entre una y otra técnica son notorias.

En el «principled balancing», la ponderación circunstancial, aunque podrá decidir finalmente el sentido de la sentencia, no podrá hacer cambiar el hecho de que nos encontramos ante un caso en el que con anterioridad ya se ha decidido si, por su conexión con el proceso político y el debate público, las restricciones a la libertad de expresión deberán juzgarse con la especial severidad propia de un escrutinio estricto, en la línea de lo apuntado en celebérrima cuarta nota a pie de página de United States contra Carolene Products 5304 US 144 (1938)]. Por ello, cuando se tengan en cuenta las circunstancias, éstas sólo podrán valorarse desde esa trascendental toma de postura previa. 
En el «ad hoc balancing», por el contrario, no se parte de ninguna consideración anterior sobre la posición que, con independencia de las circunstancias, deba concederse a la libertad de expresión por la relación que pueda tener en ese litigio con el proceso político democrático. Y como esa toma de postura previa no existe, no condiciona el valor que, en función de ella, debería darse a las circunstancias que rodean el caso, de manera que éstas despliegan todo su peso y se configuran en la práctica como el único punto a tener en cuenta para tomar una decisión. Es entonces cuando se incrementan las posibilidades de que el interés público se tome sólo como uno más de los elementos a tener en cuenta, ponderándolo con el mismo peso que el resto de las circunstancias presentes en el caso concreto. Ese sería el principal riesgo, a mi juicio, de confiar todo el peso del razonamiento jurídico al principio de proporcionalidad.

En nuestro país, el uso que se suele hacer del principio de proporcionalidad al ponderar las circunstancias concretas del caso se aproxima mucho al «ad hoc balancing». Aunque el TC formalmente decide los casos de libertad de expresión en función de si ésta se ha ejercido o no con una posición preferencial, ha sido en muchas ocasiones incapaz de diferenciar entre la presencia, que habría que detectar primero, con independencia de las circunstancias, de los criterios que permiten otorgársela o no en un supuesto concreto (fundamentalmente, su relación con la opinión pública libre) y los efectos que ello acarrea para ponderar, pero solo después, las circunstancias que lo rodean.

A primera vista parece que el TC aplica la existencia o no de posición preferente como criterio absolutamente dirimente, ya que, por lo general, siempre que se detecta, la libertad de expresión prevalece sobre cualquier otro bien jurídico que se le oponga. Pero ese decisivo papel que se le otorga es sólo aparente, pues nuestro Tribunal Constitucional no parece concebir la posibilidad de un caso en el que la libertad de expresión debiera gozar de posición preferencial, su restricción debería por ello someterse a un escrutinio estricto y, con todo, la ponderación circunstancial aconsejara que prevalecieran otros intereses o derechos.

Precisamente por ello, no ha aplicado el criterio de la posición preferencial como método de razonamiento en casos en los que, a pesar de la indudable relevancia pública del mensaje, ha terminado resolviendo que otros bienes jurídicos deben prevalecer sobre la libertad de expresión. Cuando eso sucede, el TC parece preferir decir que la posición preferente (y, con ella, el interés público que podría residir en el mensaje enjuiciado) sencillamente no está presente en el caso. Apenas encontraremos en el TC sentencias en donde se declare primero la estrecha conexión con el interés público de un mensaje, se declare por ello que cualquier restricción a la libertad de expresión debe analizarse desde un escrutinio estricto y se dictamine después que, a pesar de esa posición preferente, el mensaje ha sido legítimamente restringido.

Esa forma de razonar ha traído consigo que muy frecuentemente se trastoquen los papeles que deben tener, respectivamente, la posición preferente y la ponderación circunstancial, hasta el punto de que la primera, en lugar de 
condicionar el modo en el que se lleva a cabo la segunda, ha sido generalmente vista como su principal consecuencia: cuando el corolario de la ponderación aconseja hacer prevalecer la libertad de expresión, el TC dice que el derecho se ha ejercido con posición preferente, y cuando el resultado es el opuesto, se la niega.

La posición preferencial de la libertad de expresión no es tanto, en nuestro país, una guía para ponderar, sino, más bien, el modo de enunciar el resultado final al que se llega cuando la ponderación lleva aparejada la prevalencia de la libertad de expresión sobre otros bienes jurídicos. Por ello, en la mayoría de los casos, su uso como criterio dirimente para resolver los litigios sobre la libertad de expresión es sólo aparente: en la realidad su resolución suele ser consecuencia exclusiva de una ponderación circunstancial ad boc. Al diluirse en la propia ponderación circunstancial, sus efectos se minimizan hasta casi desaparecer, quedando en el peor de los casos reducida a una mera cláusula de estilo.

Esa confusión, a mi parecer, es la principal razón por la que la doctrina de la posición preferente no ha podido servir en España de pauta para la ponderación circunstancial, y de que sea en el seno de ésta donde se sigua encontrando, casi siempre, la auténtica ratio decidendi del TC.

\section{REMEDIO SÁNCHEZ FÉRRIZ}

Con todo lo que hasta ahora he dicho creo queda claro que confío mucho más en la teoría de la delimitación de los derechos que en la de sus límites. Los límites, por ser externos, quedan vedados incluso al legislador; sí caben los límites internos, es decir, los derivados de la propia determinación de la finalidad, ámbito y estructura de cada derecho y en este caso de la libertad de expresión. El contenido esencial se invoca para que se respete el mínimo de cada derecho sin el cual no sería recognoscible como tal categoría jurídica concreta. No parece que tal sea el problema hoy de la libertad de expresión de todos reconocida con carácter expansivo al que no se reconocen más límites que el daño «directo» a terceros. Sin embargo, sí es posible establecer un (amplio) contenido a dicha libertad que permite saber cuándo excede sus límites endógenos.

El principio de proporcionalidad, siendo un principio general, es lógico que tenga aplicación también en este caso y de hecho nuestra jurisprudencia y la del TEDH (p. ej. en la sentencia Jiménez Losantos c. España (53421/10), de 14/06/2016) lo utiliza, no sé si en exceso por cuanto comporta cierto relativismo en la determinación de los derechos enfrentados. No estoy segura, por ello, de que el solo principio sea motivación suficiente para enmendar la plana a la jurisdicción nacional, pero así parece decidirlo la de Estrasburgo: «Pese a que las razones en las que basaron sus decisiones los tribunales nacionales pudieran ser pertinentes, la sanción impuesta sería desproporcionada al fin perseguido...».

Se trata de un principio auxiliar de la jurisdicción que ha de aplicarse al caso concreto para valorar la preponderancia de uno u otro de los derechos en conflicto 
en cada caso concreto, aunque, como ya he dicho, no creo que deba aplicarse en nuestro ordenamiento sistemáticamente sino en los casos más complejos en que pudiera representar un último elemento a considerar cuando, tras delimitar tales derechos, no fuera posible la decisión. Sin embargo, es sabido que el TC lo introduce como elemento decisivo al proclamar (S. 112/2016): a) El carácter institucional del derecho a la libertad de expresión; b) el carácter limitable del derecho a la libertad de expresión y, singularmente, el derivado de manifestaciones que alienten la violencia y e) la proporcionalidad en la limitación penal del ejercicio del derecho a la libertad de expresión. Creo que estamos ante una incoherencia pues no deberíamos alentar la convivencia de a y de b. Si hay una no puede haber otra.

Retomando, para concluir, la primera de las preguntas diría que la proporcionalidad es un principio que debería tenerse en cuenta a la hora de juzgar y valorar los mensajes polémicos que hoy invaden las nuevas redes sociales; puesto que en ellas el insulto, la amenaza o la humillación de cualquier tipo, siendo más fácil, debe juzgarse también teniendo en cuenta la posición del negativamente afectado pues este (individual, colectivo o incluso institución) carece de las posibilidades de reacción que el quejoso sí tiene o puede tener frente a los medios tradicionales.

\section{JOAQUIN URÍAS MARTÍNEZ}

Este es el punto esencial a la hora de tratar la libertad de expresión como un auténtico derecho fundamental. Ni la técnica de la ponderación ni el principio de proporcionalidad sirven para definir el contenido protegido del derecho. Ambos son mecanismos extraordinarios que permiten controlar la adecuación de la regulación legal de su ejercicio o el conflicto entre el carácter institucional como principio de ambos derechos. Carece, sin embargo, de toda lógica jurídica y constitucional la creencia de que los operadores jurídicos deben tomar en cuenta las circunstancias de cada caso concreto para decidir si aplican o no los derechos fundamentales. Sin embargo, aunque tal concepción sea contraria a la idea misma de eficacia jurídica de los derechos, eso es precisamente lo que suelen hacer nuestros tribunales, con el constitucional a la cabeza.

Esta pérdida total del valor jurídico de la libertad de expresión tiene una causa histórica y otra jurisprudencial. Históricamente, la libertad de expresión ha sido siempre un principio sometido al poder. Las experiencias previas a 1978 se han basado siempre en que es posible defender la libertad de expresión y al mismo tiempo prohibir la expresión de determinados contenidos ideológicos contrarios al poder. La plasmación de esta idea en el fuero de los españoles de 1945 es clarísima: «Todo español podrá expresar libremente sus ideas mientras no atenten a los principios fundamentales del Estado». Muchos juristas firmarían hoy día sin pestañear una declaración similar, pese a su sentido contradictorio. En sentido la 
libertad de expresión no ha perdido eficacia jurídica como derecho, sino que seguramente nunca ha llegado a adquirirla.

La segunda causa tiene que ver con la falta de finezza de nuestro Tribunal Constitucional a la hora de delimitar la libertad de expresión. Los derechos fundamentales tienen un doble carácter; de una parte, son derechos subjetivos con plena eficacia jurídica frente a todos los poderes públicos, incluido el legislativo. De otra parte, actúan como principios que inspira la actuación del poder público que está obligado a optimizarlos creando las condiciones que mejor permitan su desarrollo. Para dotar de eficacia a su faceta de derechos subjetivos es imprescindible delimitar un contenido esencial protegido e intangible. Ese núcleo no puede ser restringido en ningún momento, aunque sólo pueda ponerse en práctica en el marco de las condiciones de ejercicio establecidas legalmente. En materia de libertad de expresión el Tribunal Constitucional ha sido incapaz de delimitar siquiera de modo genérico el contenido esencial de la libertad de expresión y ha preferido tratarla sólo como un principio que vincula de modo genérico a los poderes públicos pero que puede ceder ante cualquier interés digno de protección constitucional. El resultado es una tremenda inseguridad jurídica en la que la ciudadanía nunca puede contar de antemano con protección constitucional para usar su libertad de expresión. Ha dejado de ser un derecho.

Frente a ello, es posible y necesario profundizar en la delimitación de la libertad de expresión. Hay que comenzar por admitir que la Constitución no protege cualquier expresión. No hay en nuestro sistema una garantía genérica de la comunicación. La comprensión amplia de que cada vez que una persona diga o escriba algo estaría ejerciendo su libertad de expresión sólo sirve para devaluar su fuerza jurídica. Cualquier interpretación sistemática lleva a la conclusión de que nuestro texto constitucional quiere dar inmunidad exclusivamente a la transmisión pública de ideas con relevancia democrática. Esta mera constatación serviría para dejar fuera del ámbito protegido por el derecho subjetivo muchas expresiones que no son una manifestación de la conducta protegida; sin necesidad de ponderación o juicio de proporcionalidad.

Así, quien usa la comunicación con otra persona para amenazarla no pretende transmitir ideas con relevancia democrática, sino determinar los actos de la persona afectada. Resulta del todo irregular entender que ese acto comunicativo que no transmite ideas, sino que incide sobre la realidad, esté protegido como libertad de expresión. Es algo simplemente ajeno al derecho fundamental entendido como derecho subjetivo. Igual sucede con quien usa la palabra con la intención de humillar a otra persona, o para comprar fruta, o intentando incitar a que se cometa un delito. Todos estos casos no pueden presentarse técnicamente como limitaciones de la libertad de expresión, simplemente porque no son libertad de expresión ya que en ellos no se busca la transmisión de una idea sobre el funcionamiento de la sociedad.

El Tribunal Constitucional, en cambio, ha recurrido a una técnica menos rigurosa con la noción de derecho fundamental y que tiene peligrosas 
consecuencias cuando se extiende al poder judicial en su tarea de garante de los derechos. En vez de constatar que en todos estos casos la conducta realizada no coincide con el contenido esencial de la libertad de expresión, prefiere tratarlos como casos en los que sí hay libertad de expresión, pero el derecho fundamental cede ante otros intereses. Ello ha contribuido a devaluar la categoría y a incrementar la inseguridad jurídica, al tiempo que ha abierto la puerta para que en los casos en los que realmente se pretende la transmisión de una idea con relevancia para el funcionamiento democrático de la sociedad se prohíba el ejercicio del derecho fundamental.

En ese sentido sería deseable una jurisprudencia con mayor rigor en el uso de las categorías técnicas. Debería dejar clara la diferencia entre el carácter institucional de la libertad de expresión que se concreta en lo que el propio Tribunal ha llamado 'una comunicación pública libre' y su valor como derecho subjetivo que sólo protege la transmisión de ideas con relevancia pública. A partir de esas premisas resulta más fácil ir definiendo caso por caso qué significa idea y qué significa relevancia, así como resolver los casos en los que concurren varias intenciones sobre un mismo acto comunicativo. La construcción de esa jurisprudencia incrementaría la seguridad jurídica y permitiría resolver de una vez cuestiones que inexplicablemente permanecen abiertas como es, entre otras, la de la relación entre tipos penales que persiguen las amenazas, los insultos o la incitación directa al delito y la libertad de expresión.

\section{IGNACIO VILLAVERDE MENÉNDEZ}

Estas preguntas apuntan a un aspecto crucial no sólo de la teoría de la libertad de expresión, sino de la teoría general de los derechos fundamentales y sus relaciones con el resto del ordenamiento jurídico. En último término, la proporcionalidad es una técnica de resolución de conflictos entre normas que aspiran a regular de forma contradictoria una misma realidad. La ponderación es otra técnica que persigue el mismo objetivo. Pero la primera trata de resolver el conflicto sin alterar la relación de igualdad jerárquica que media entre las normas en conflicto, mientras que la segunda ordena jerárquicamente las normas según las circunstancias de cada caso y los fines que en cada circunstancia se persiguen por considerarlos más valiosos. La diferencia radical entre una técnica y otra estriba en la posición del intérprete que está llamado a resolver el conflicto. En el primer caso su papel es muy secundario porque el conflicto se resuelve a través del juego recíproco de varios criterios (necesidad, adecuación y proporcionalidad) que en realidad persiguen domeñar el voluntarismo del intérprete obligándole a hacer explícito un proceso de argumentación en la aplicación sucesiva de esos elementos de juicio. En el segundo caso el papel del intérprete es decisivo, porque la técnica ponderativa deja a su albur la decisión sobre qué derecho vale más en cada caso atendiendo a sus circunstancias. Lo que también debe razonar, desde luego, 
pero con criterios mucho más evanescentes y difíciles de contrastar y de predecir el resultado de ese razonamiento. En definitiva, en el Derecho somos (debemos ser) método y no voluntad.

Con la fuerza expansiva que tiene la libertad de expresión (el modelo norteamericano es un claro ejemplo de ello), el uso del método ponderativo en la resolución de sus conflictos con otros derechos siempre conduce a una solución de «todo o nada». De hecho, la tendencia en modelos ponderativos es que la libertad de expresión termina por funcionalizarse (su garantía constitucional depende de la satisfacción de ciertos valores supuestamente constitucionales), y si en el caso concreto su ejercicio se considera por el intérprete que satisface los valores a los que sirve niega (anula) cualquier otra norma que se le oponga (por ejemplo, el derecho al honor, que siempre se sacrificará en aras de la más alta función democrática de la libertad de expresión). Esto no sólo plantea serios problemas técnicos (García Amado en su último libro así lo apunta), sino que supone una insostenible jerarquización de las normas constitucionales. La proporcionalidad es la técnica que permite mantener ese frágil equilibrio entre normas constitucionales, sustraído de la voluntad del intérprete.

$$
* * *
$$

TITLE: Academic survey about freedom of speech

ABSTRACT: In this academic survey a group of Constitutional Law Professors answer some questions about the freedom of speech and its challenges in the digital society, about the called «hate speech», the ECHR doctrine on freedom of speech, the limits and limitations of this right, and the classical conflict with honor and privacy.

Resumen: En esta encuesta un grupo de profesores de Derecho Constitucional contestan un conjunto de preguntas sobre la libertad de expresión, los retos que debe afrontar en la sociedad digital, los llamados discursos del odio, la jurisprudencia del Tribunal Europeo de Derechos Humanos sobre esta libertad, sus límites y ámbito protegido, y sobre el clásico conflicto con el honor y la intimidad de las personas.

KEY WORDS: freedom of speech, digital society, hate speech, freedom of speech limits, conflict with honor and privacy.

Palabras clave: libertad de expresion, sociedad digital, discurso del odio, limites de la libertad de expresion, conflicto con el honor y la intimidad. 
